\title{
METODOLOGIAS DE ENSINO NA EDUCAÇÃO À DISTÂNCIA EM CIÊNCIA DA SAÚDE: FORMAÇÃO LATO SENSU.
}

Tese apresentada ao Programa de Pós-Graduação em Gerenciamento em Enfermagem da Escola de Enfermagem da Universidade de São Paulo para obtenção do título de Doutora em Ciências.

Área de concentração: Fundamentos e Práticas de Gerenciamento em Enfermagem e em Saúde.

Orientadora: Profa. Dra. Maria de Fátima Prado Fernandes 
AUTORIZO A REPRODUÇÃO E DIVULGAÇÃO TOTAL OU PARCIAL DESTE TRABALHO, POR QUALQUER MEIO CONVENCIONAL OU ELETRÔNICO, PARA FINS DE ESTUDO E PESQUISA, DESDE QUE CITADA A FONTE.

Assinatura:

Data:

\section{Catalogação na Publicação (CIP) \\ Biblioteca "Wanda de Aguiar Horta" \\ Escola de Enfermagem da Universidade de São Paulo}

Carlin, Daniele Soares

Metodologias de ensino na educação à distância em ciência da saúde: formação lato sensu / Daniele Soares Carlin. São Paulo, 2019.

$92 \mathrm{p}$.

Tese (Doutorado) - Escola de Enfermagem da Universidade de São Paulo.

Orientadora: Prof. ${ }^{a}$ Dr. ${ }^{a}$ Maria de Fátima Prado Fernandes

Área de concentração: Fundamentos e Práticas de Gerenciamento em Enfermagem e em Saúde

1. Educação à distância. 2. Métodos de ensino. 3. Curso de especialização. 4. Ciências da saúde. 5. Enfermagem. I. Título.

Ficha catalográfica elaborada por Fabiana Gulin Longhi Palacio (CRB-8: 7257) 
Nome: Daniele Soares Carlin

Título: Metodologias de Ensino na Educação à Distância em Ciência da Saúde: formação lato sensu.

Tese apresentada ao Programa de Pós-Graduação em Gerenciamento em Enfermagem da Escola de Enfermagem da Universidade de São Paulo para obtenção do título de Doutora em Ciências.

Aprovado em:

Banca Examinadora

Orientador: Profa. Dra. Maria de Fátima Prado Fernandes Instituição: EEUSP Assinatura:

Prof. Dr. Instituição:

Julgamento: Assinatura:

Prof. Dr. Instituição:

Julgamento: Assinatura:

Prof. Dr. Instituição:

Julgamento: Assinatura:

Prof. Dr. Instituição: Julgamento: Assinatura:

Prof. Dr. Instituição: Julgamento: Assinatura: 



\section{DEDICATÓRIA}

Ao meu marido e companheiro de todas as horas Alexander, por estar sempre ao meu lado, mesmo quando eu mesma não quería estar. Você faz parte de tudo isso.

Aos meus fílhos João Pedro, Clara e Aurora por acreditarem sempre que em algum momento eu viraria mamãe de novo. Sem vocês me mostrando o quanto tudo vale a pena, a mamãe não conseguíría.

À minha mãe, por fazer maís que o possível para me apoiar nessa empreitada, acreditando em minha capacidade como só as mães são capazes.

À Carolina, Heloisa e Julia por tornarem os momentos difíceis mais leves e felizes.

Em memóría de meus avós, Margarida, Alfredo e Címira, que sempre tanto acreditaram em mim. 



\section{AGRADECIMENTOS}

$\mathcal{A}$ Deus, pela coragem diáría, força e confíança nos momentos de incertezas e medos.

À orientadora, Profa ${ }^{a} r^{a}$ Maria de Fátima Prado Fernandes, pela competêncía, respeito, paciêncía e amorosidade com que conduziu este estudo.

Ao programa de Pós-Graduação em Gerenciamento em Enfermagem - PPGEn, pela concessão da bolsa de doutorado, que possibilitou minha dedicação plena a esse estudo.

À querida Márcía, funcionárias do Serviço de Pós-Graduação, pela paciêncía e ajuda nos momentos de dúvidas.

Aos professores, tutores e coordenadores dos cursos latu sensu em educação a distâncía nas áreas da saúde, pela disponibilidade e interesse em contribuir com esse estudo.

À minha família por estar sempre presente, mesmo quando eu não estava.

Muito Obrígada, 

(EPÍGRAFE)

"Leve na sua memória para o resto de sua vida, as coisas boas que surgiram no meio das dificuldades. Elas serão uma prova de sua capacidade em vencer as provas e lhe darão confiança na presença divina, que nos auxilia em qualquer situação, em qualquer tempo, diante de qualquer obstáculo."

Chico Xavier 

Carlin DS. Metodologias de Ensino na Educação à Distância em Ciência da Saúde: formação lato sensu. [tese]. São Paulo: Escola de Enfermagem, Universidade de São Paulo; 2019.

\section{RESUMO}

Introdução: Com o avanço das Tecnologias de Informação e Comunicação a maneira como as pessoas buscam conhecimento e se relacionam têm se modificado de forma rápida. Esse avanço trouxe novas ferramentas que permitiram a expansão dos cursos na modalidade de Educação a Distância - EaD - que viabiliza aos estudantes e profissionais de saúde, a possibilidade de se especializarem (lato sensu), quando um curso presencial não cabe em sua rotina, proporcionando um maior acesso à especialização, sobretudo no âmbito das ciências da saúde. As metodologias de ensino utilizadas no uso dessas ferramentas são essenciais para viabilizar a qualidade do processo de ensino aprendizagem. Objetivo: Identificar o papel das metodologias de ensino utilizadas em cursos lato sensu na modalidade EaD nas áreas das Ciências da Saúde no Brasil. Método: pesquisa qualitativa descritiva. Os sujeitos da pesquisa foram professores/coordenadores de cursos lato sensu nas áreas da saúde oferecidos na modalidade de $\mathrm{EaD}$. Estes preencheram um formulário acerca das ferramentas e metodologias de ensino utilizadas nesses cursos e participaram de entrevista semiestruturada com questões norteadoras pertinentes ao tema. Para análise dos dados utilizou-se o método de análise de conteúdo sob os conceitos da teoria sóciointeracionista de Vygotsky Resultados: a análise dos dados resultou em quatro categorias pertinentes ao objeto de estudo. Reflexões acerca dos cursos oferecidos na modalidade EaD; Acesso aos cursos de especialização; O papel das Tecnologias de Informação e comunicação; e, com destaque para A importância das metodologias de ensino para os cursos lato sensu das áreas da saúde. Conclusões: A EaD traz uma nova realidade para a expansão e aprofundamento de conhecimento. Existe uma preocupação com a qualidade do ensino, direcionada a necessidade de atualização e adequação das metodologias aplicadas ao uso das ferramentas utilizadas nos cursos oferecidos nessa modalidade. A EaD proporciona a ampliação do acesso à qualificação dos profissionais pela maior adesão a essa modalidade de ensino, visando a melhoria da assistência de saúde para a população.

PALAVRAS-CHAVE: Educação a Distância; Métodos de Ensino; Curso de Especialização; Ciências da Saúde. 

Carlin DS. E-learning teaching methodologies in health sciences: lato sensu academic training. [thesis]. São Paulo: Escola de Enfermagem, Universidade de São Paulo; 2019.

\begin{abstract}
Introduction: With the advancement of Information and Communication Technologies, the way people search knowledge and relate has changed quickly. This improvement has brought new tools which have allowed the expansion of e-learning which enables students and health professionals the possibility of specializing (lato sensu), when a presencial class does not fit in their routine, providing greater access to specialization, especially in the health sciences. The teaching methodologies used in the use of these tools are essential to enable the quality of the teaching-learning process. Objective: To identify the role of teaching methodologies used in lato sensu classes of e-learning in the Health Sciences areas at Brazil. Method: descriptive qualitative research. The research subjects were professors/coordinators of lato sensu courses in the health areas offered in e-learning modality. They completed a form about the teaching tools and methodologies used in these classes and participated in a semi-structured interview with guiding questions pertinent to the subject. For data analysis was used the content analysis method under the concepts of Vygotsky's socio-interactionist theory. Results: Data analysis resulted in four categories pertinent to the object of study. Observations on the classes offered in the distance education modality; Access to specialization classes; The role of information and communication technologies; and, especially, the importance of teaching methodologies for lato sensu classes in health areas. Conclusions: E-learning brings a new reality to the expansion and deepening of knowledge. There is a concern with the quality of teaching, directed to the need to update and adapt the methodologies applied to the use of tools used in the classes offered in this modality. E-learning provides the widening of access to the qualification of professionals by greater adherence to this education way, aiming at improving health care to population.
\end{abstract}

KEYWORDS: E-learning; Teaching Method; Specialization Classes; Health Scienses 



\section{LISTA DE SIGLAS}

AVA - Ambiente virtual de aprendizagem

CAPES - Coordenação de Aperfeiçoamento de Pessoal de Nível Superior CEP - Comitê de Ética em Pesquisa

CES - Câmara de Educação Superior

CNE - Conselho Nacional de Educação

$\mathrm{CP}$ - Conselho Pleno

EaD - Educação à Distância

EEUSP - Escola de Enfermagem da USP

IES - Instituições de Educação Superior

LDB - Lei de Diretrizes e Bases

MBA - Master Business Administration

MEC - Ministério da Educação e Cultura

Moodle - Modular Object-Oriented Dynamic Learning Environnent

TCLE - Termo de Consentimento Livre e Esclarecido

TIC - Tecnologias de Informação e Comunicação

UNIVESP - Universidade Virtual do Estado de São Paulo 



\section{SUMÁRIO}

1 Introdução 18

1.1 CONTEXTUALIZAÇÃO DO TEMA 18

1.2 EXPLICITAÇÃO DO PROBLEMA 20

1.3 JUSTIFICATIVA/RELEVÂNCIA DO ESTUDO 21

2 Objetivo 23

2.1 Objetivo Geral 23

2.2 Objetivos específicos__ 23

3 Achados Conceituais__ 25

3.1 Metodologias de Ensino__ 25

3.2 Educação a Distância___ 27

3.2.1 Definições ____ 27

3.2.2 Histórico da EaD ___ 28

3.2.2 Leis brasileiras que regem a EaD nos cursos de pós-graduação___ 32

3.3 Cursos lato sensu__ 34

4 Referencial Teórico Pedagógico___ 35

5 Percurso Metodológico__ 37

5.1 Delineamento do estudo___ 37

5.2 Locais do estudo ___ 38

5.3 Critério de inclusão ___ 38

5.4 Descrição dos instrumentos e procedimentos da coleta de dados___ 38

5.5 Análise dos dados___ 41

5.6 Aspectos Éticos da Pesquisa ___ 42

6 Análise e Discussão de dados___ 43

7 Conclusão__ 73

8 Considerações Finais___ 75

9 Referências___ 77

10 Obras Consultadas___ 83

11 Apêndices__ 85

Apêndice 1 — 85

Apêndice 2 — 87

Apêndice 3 _ 91 

Introdução 


\section{INTRODUÇÃO}

Ingressei na Escola de Enfermagem da Universidade de São Paulo (EEUSP) em 2005 e me formei em 2008. Essa informação é muito importante porque esse foi um período em que vivenciamos uma aceleração tecnológica, aumento da inclusão digital e acesso às Tecnologias de Informação e Comunicação (TIC) pela população brasileira, principalmente nos grandes centros.

Isso possibilitou que as TICs começassem a ser usadas e exploradas como ferramentas para apoiar o ensino. Nesse contexto, o surgimento da primeira versão do Moodle em 2002 foi um grande salto, pois facilitou e, portanto, popularizou seu uso pelas instituições de ensino. ${ }^{1}$

Diante disso, vivenciei os primeiros usos da plataforma como apoio ao ensino presencial na graduação. Como era o início do uso dessa ferramenta de ensino, confesso que fiquei cética sobre sua eficiência, afinal venho de uma formação no ensino tradicional.

Finalizei a graduação e durante meus anos de licenciatura e mestrado tive a possibilidade de fazer alguns cursos de aprimoramento e atualização usando o modelo de Educação à Distância (EaD). Em 2014 também tive a experiência de ingressar na primeira turma do curso de graduação em engenharia de produção oferecido no modelo EaD pela Universidade Virtual do Estado de São Paulo (UNIVESP).

Essas experiências ampliaram minha visão e me apresentaram uma nova possibilidade de ensino que, em alguns casos mostrou-se eficaz e em outros nem tanto.

Pensando sobre isso, percebi que a metodologia de ensino influenciava diretamente a funcionalidade das ferramentas disponíveis nesses cursos e que os projetos que se preocupavam realmente com as metodologias de ensino entregavam uma experiência educacional mais completa. 
Portanto, tendo em vista a complexidade e, em parte, o receio acerca do uso da EaD nos cursos da área da saúde e, ao mesmo tempo, o potencial de difusão do conhecimento que esse modelo propicia, decidi pesquisar como as metodologias de ensino estão sendo utilizadas nos cursos lato sensu oferecidos hoje no Brasil.

\subsection{CONTEXTUALIZAÇÃO DO TEMA}

A sociedade humana vive em constante evolução, principalmente no que diz respeito às inovações tecnológicas. No último século estas aconteceram de forma acelerada, devido, em grande parte, aos avanços nas TIC. ${ }^{2}$

Esses avanços nas TICs não poderiam passar despercebidos pelo ensino e produção de conhecimento. Com relação à educação, os objetos digitais podem contribuir para o desenvolvimento de estratégias de ensino enriquecedoras, propiciando dinamismo e construção ativa do conhecimento no processo de ensinoaprendizagem ${ }^{2}$. Porém, para que essas características sejam alcançadas, é preciso que o planejamento pedagógico seja coerente e tenha uma definição clara dos objetivos educacionais pretendidos. ${ }^{3,4}$

Este cenário possibilitou o desenvolvimento e modernização da $\mathrm{EaD}$, que hoje é tida como uma modalidade educacional desenvolvida, integralmente (e-learning) ou parcialmente (blended-learning), com a separação física entre professores, alunos e conteúdos instrucionais, que interagem por meio das $\operatorname{TIC}^{5,6}$. Essa interação depende do envolvimento dos atores que fazem parte do referido processo de ensinoaprendizagem (estudantes, professores, tutores, instituições de ensino, empresas, governos e etc.).

Portanto, educar à distância é fazer uso dos recursos necessários de comunicação, didáticos e metodológicos, para que o processo de ensinoaprendizagem aconteça sem a integração espacial e temporal síncrona entre estudantes e professores. ${ }^{7}$

Essa modalidade, voltada a aprendizagem de jovens e adultos, está apoiada em vários princípios educacionais, entre eles a aprendizagem aberta e a educação permanente ${ }^{7}$. Isso se deve ao fato de ser uma estratégia de difusão do conhecimento 
que oportuniza o tempo, dando flexibilidade para as pessoas escolherem o melhor momento e local de acesso. ${ }^{8}$

As discussões sobre EaD no ensino lato sensu, além de suas especificidades e singularidades, são acerca de seus limites e possibilidades. As duas maiores questões a respeito do tema são sobre a qualidade, ou seja, os critérios para afirmar ou negar sua implantação ou aceitação como possibilidade de trabalho ou formação; e sobre as especialidades ou campos de formação nas quais ela pode ser usada. ${ }^{9}$

Nas ciências da saúde, especificamente, os primeiros usos de EaD datam do final da década de 90 (muito depois de sua ascensão global, que foi na década de $60)$. Estes cursos usavam recursos tridimensionais e audiovisuais que simulavam, com segurança, as intervenções relativas ao processo de tratamento. ${ }^{10}$

Com as mudanças ocasionadas pelo processo de informatização, o modo de conhecer e aprender também vêm se modificando. A informática tem causado debates, análises e questionamentos sobre como integrá-la aos processos educativos. Desta forma, era de se esperar que as instituições que oferecem cursos de pós-graduação lato sensu nas áreas das Ciências da Saúde no Brasil considerassem o ensino através de ambientes virtuais de aprendizagem e suas possibilidades. ${ }^{11.12}$

Paralelamente, temos que considerar que o Brasil é um país de dimensões continentais, portanto, qualquer iniciativa na intenção de levar formação adequada aos profissionais de saúde, de forma a transpor as dificuldades da formação presencial será muito bem vinda. ${ }^{13}$

Neste sentido, o uso da internet na qualificação desses profissionais pode ser um meio de levar aperfeiçoamento profissional constante e de qualidade através do acesso a sites de universidades e de revistas cientificas, além da possibilidade de entrarem em contato com seus pares para a troca de informações, o que é condição fundamental para a capacitação pessoal. ${ }^{14}$

No cenário atual brasileiro, a EaD assume uma natureza interdisciplinar baseada na troca de conhecimentos científicos. Nesse campo, o avanço tecnológico está cada vez mais rápido, e a inclusão de universidades corporativas, universidades 
abertas à distância, inclusão digital, novas metodologias de ensino como a aprendizagem autodeterminada, redes educacionais abertas, TV Digital, e etc, tornam a disseminação do conhecimento cada vez mais acessível. ${ }^{5}$

A aplicação dessas tecnologias na educação em ciências da saúde implica na necessidade de desenvolvimento de metodologias de ensino/aprendizagem adequadas, para que o EaD possa ser utilizado como mecanismo complementar, parte integrante do ensino presencial, ou ainda, ser inteiramente substitutivo.

\subsection{EXPLICITAÇÃO DO PROBLEMA}

O grande avanço que as TIC tiveram na contemporaneidade acabou alterando as expectativas e atitudes dos estudantes, que esperam que parte de seus estudos acadêmicos incluam EaD. Esta modalidade de ensino é muito popular entre os estudantes porque pode ser acessada de qualquer lugar, de acordo com sua conveniência e por permitir a revisão dos conteúdos quantas vezes sejam necessárias.

Para as instituições de ensino também pode ser interessante porque permite flexibilidade nos horários e na constituição das turmas, que deixam de ser dependentes de espaço físico, tornando os custos muito mais atraentes, principalmente a longo prazo. ${ }^{15}$

Com o uso das novas tecnologias de informação desenvolvidas para a EaD, tornou-se possível concatenar conhecimentos norteadores de uma prática profissional, que além de atender a demanda dessa nova geração, forma esses futuros profissionais para uma prática engajada no mercado de trabalho que eles vão vivenciar. ${ }^{16}$

Portanto, precisamos aceitar que o uso das TICs para a formação dos profissionais de várias áreas do conhecimento, inclusive da saúde, têm sido uma tônica nos discursos educacionais. Essa realidade está sendo ampliada também nos cursos lato sensu nas ciências da saúde, mas ainda em alguns espaços educacionais prevalecem metodologias de ensino que, apesar de serem consideradas EaD, pouco diferenciam do ensino tradicional. 


\subsection{JUSTIFICATIVA/RELEVÂNCIA DO ESTUDO}

Em busca bibliográfica realizada em março de 2016 nas bases de dados que compõem a Biblioteca Virtual em Saúde - BVS, nenhum estudo relevante retornou às palavras-chave - metodologia, educação a distância e saúde - e suas variações em português ou inglês.

Excluindo a palavra-chave - metodologia - foram encontrados vários estudos, nacionais e internacionais, a respeito de $\mathrm{EaD}$ e ciências da saúde. A maioria desses estudos estão focados nas experiências dos estudantes com o ambiente virtual de aprendizagem (AVA), uso de TICs para acesso aos materiais dos cursos oferecidos e, principalmente, em simulações e treinamentos.

Portanto, diante dessa realidade, novos estudos com o objetivo de desenvolver e aprimorar novos métodos de ensino, aprendizagem e de avaliação dos estudantes de cursos lato sensu, que envolvem EaD são muito importantes para a qualidade da formação dos profissionais da saúde no Brasil. Assim, esse estudo se faz relevante, pois poderá contribuir para elucidar como as metodologias de ensino estão sendo utilizadas nessa área, a aceitação pelos estudantes, professores e tutores, focando na eficácia desses métodos e no processo da aprendizagem.

Neste estudo, ao investigar as metodologias de ensino utilizadas na EaD, entende-se que além de ser algo diferenciado, precisa ser essencialmente útil, trazendo ao ensino ganhos para a formação dos estudantes e proporcionando novos meios de aprendizagem para os profissionais. É certo que toda inovação passa por um processo que deve ser gerenciado e avaliado, para que o necessário para sua efetivação esteja garantido antes de qualquer movimento para sua implementação. 



\section{Objetívos}




\section{OBJETIVOS}

\subsection{Objetivo Geral}

Identificar o papel das metodologias de ensino utilizadas em cursos lato sensu na modalidade Educação à Distância - EAD nas áreas das Ciências da Saúde no Brasil.

\subsection{Objetivos específicos}

a. Retratar como os professores dialogam com seus pares acerca do EaD.

b. Descrever as metodologias de ensino utilizadas em cursos lato sensu que na modalidade EAD nas áreas das Ciências da Saúde no Brasil;

c. Destacar o papel das metodologias de ensino para o desenvolvimento desses cursos.

d. Articular possíveis reflexões dos professores sobre a transição entre as diferentes modalidades de ensino (EaD e presencial). 



\section{Achados conceituaís}




\section{ACHADOS CONCEITUAIS}

\subsection{Metodologias de Ensino}

Podemos definir metodologias de ensino como os métodos e/ou técnicas utilizados como orientação pelos professores, coordenadores ou desenvolvedores de cursos e/ou disciplinas para o desenvolvimento do ensino visando uma aprendizagem efetiva. Os métodos são os meios que dependem da concepção metodológica do processo educativo, como os conteúdos e habilidades que se pretende transmitir, e como serão utilizados para atingir os objetivos propostos. Por sua vez, as técnicas são as formas como os métodos serão desenvolvidos, ou seja, os modelos sistemáticos de passos, procedimentos e ações que serão utilizados pelo professor. ${ }^{17}$

O planejamento do ensino e, portanto, o uso dos métodos e técnicas adequadas, vai depender de vários fatores que deverão ser observados e avaliados, pois dependem das características, condições e circunstâncias dos estudantes, dos professores e do ambiente envolvidos no processo de ensino aprendizagem, pois estes estudantes devem se utilizar dos conhecimentos adquiridos para seu uso na vida real. ${ }^{17}$

Isso posto, podemos concluir que as metodologias de ensino devem estar articuladas com as técnicas possíveis de serem utilizadas em dado contexto de ensino aprendizagem, onde se juntam como um conjunto de processos com o objetivo de executar o plano de ensino. ${ }^{18}$

Podemos distinguir quatro modalidades básicas entre as metodologias de ensino: Metodologias de ensino individualizadas, Metodologias de ensino socializadas, Metodologias de ensino sócio-individualizadas e Metodologias de ensino expositivas dialogadas. ${ }^{19,20}$

Essas modalidades de metodologias de ensino podem ser definidas da seguinte maneira:

- Metodologia de ensino individualizada: o professor foca as tarefas e suas execuções no estudante de forma singular, ou seja, este deve as cumprir individualmente, como um estudo dirigido, por exemplo. ${ }^{18}$ 
- Metodologia de ensino socializada: o foco principal desse tipo de metodologia de ensino é o trabalho em grupo, que objetiva a integração social do estudante, visando o desenvolvimento da capacidade de se expressar e defender ideias. Bons exemplos desse tipo de ensino são as discussões em grupos e os seminários. ${ }^{18}$

- Metodologias de ensino sócio-individualizadas: visa a interação entre professor e estudante, pretendendo o desenvolvimento de novos conhecimentos e habilidades, além da reflexão sobre os mesmos. Podemos usar como exemplo dessas metodologias a problematização e a pesquisa. ${ }^{18}$

- Metodologia de ensino expositiva dialogada: aqui, o professor é o responsável por apresentar, explicar e demonstrar conteúdos e habilidades, tornando o estudante um receptor de conteúdo. Porém, idealmente, deve-se tomar cuidado para que o estudante não seja um ator passivo no processo de ensino aprendizagem. Para isso, práticas como memorização sem foco em compreensão, a não preocupação em alinhar o conteúdo com a realidade do estudante, coibir a participação do estudante durante a exposição dos conteúdos, exigir na avaliação respostas que reproduzem literalmente o conteúdo transmitido e a não consideração das diferenças e realidades individuais dos estudantes, devem ser evitadas, já que podem ser consideradas as grandes vilãs desse tipo de metodologia de ensino. ${ }^{20}$

Dessa forma, as metodologias de ensino são importantes para o ajuste de possibilidades em sala de aula. Sendo assim, as metodologias de ensino também dependem dos comportamentos, atitudes e características do professor que mediará o processo de produção de conhecimento, podendo ser então classificadas como subjetivas, pois cada professor tem seu estilo próprio e essa particularidade abre diferentes possibilidades e caminhos a serem seguidos durante o processo de ensino aprendizagem. ${ }^{21}$

Esses estilos podem ser divididos em 4 categorias ${ }^{22}$, explanadas a seguir:

- $\quad$ Professor motivador: aquele que dá preferência para o desenvolvimento pessoal e social do estudante frente ao conteúdo a ser trabalhado.

- $\quad$ Professor expositor: se destaca por ser autoritário e preferir aulas tradicionais com transmissão de conteúdo. 
- Professor tutor: busca a independência dos estudantes, visando o aprimoramento das habilidades profissionais.

- $\quad$ Professor inovador: tem como característica principal a habilidade em estimular os estudantes a se autodescobrirem, fazendo uso da aprendizagem experimental, por vezes utilizando metodologias de ensino não convencionais.

Com o surgimento das TICs, tanto os professores quanto as metodologias e técnicas de ensino estão passando por um enorme processo de mudança, diante do surgimento de novas ferramentas para o desenvolvimento e transmissão de conteúdos. Ferramentas essas que estão se inserindo em todos os espaços de ensino aprendizagem, sejam eles presenciais, semipresenciais ou totalmente à distância. ${ }^{23}$

Portanto, podemos perceber que o processo de ensino e aprendizagem depende das metodologias de ensino, inclusive, para a utilização das diferentes ferramentas didático-pedagógicas que surgem a cada dia, principalmente na EaD.

\subsection{Educação a Distância}

\subsubsection{Definições}

De forma ampla, EaD pode ser definida como a que se realiza sem a necessidade da presença de estudantes e professores ao mesmo tempo nem no mesmo local.

A EaD consiste no processo de ensino aprendizagem planejado, acontecendo em lugares diferentes dos tradicionais locais de ensino. Necessita de metodologias e técnicas diferenciadas de criação de curso e de instrução, utilizando várias tecnologias como meios de comunicação e disposições organizacionais e administrativas adequadas. ${ }^{24}$

Existem, contudo, outras nomenclaturas disponíveis que procuram definir a EaD de acordo com suas características ou modalidades, como, por exemplo, ensino por correspondência, e-learning e blended-learning. Os dois últimos termos vêm 
sendo utilizados, principalmente nos Estados Unidos da América e na Europa para definir o estudo por meio eletrônico, mais especificamente que utiliza a internet como meio de comunicação e disposição de materiais. E-learning se referindo à Educação totalmente à distância e blended-learning como ensino misto, ou seja, que ocorre parte presencialmente e parte por meio da internet.

A criação desses cursos depende não apenas das tecnologias de comunicação e de disseminação de conteúdos, mas também de profissionais capacitados para usar metodologias e técnicas de ensino adequadas às ferramentas utilizadas no desenvolvimento desses cursos.

Com o surgimento das novas TICs a particularidade "distância" começou a ser, de certa forma, diminuída, pois o espaço físico passou a ser substituído pelo espaço virtual. Assim, é esperado que os estudantes de cursos de EaD se relacionem com os outros atores do curso, com a finalidade de converter os conteúdos disponibilizados no material através das diversas mídias, em conhecimento real, considerando suas características e realidades pessoais. ${ }^{25}$

\subsubsection{Histórico da EaD}

Apesar de estarmos vivendo o momento de expansão e difusão massiva da EaD, por ser definida como a possibilidade de educação que promove o ensino de pessoas separadas espaço-temporalmente, ela não é uma novidade. Podemos encontrar indícios de sua prática desde a invenção da escrita, onde esta era utilizada para troca de informações e experiências.

As cartas de Platão e as Epístolas de São Paulo, datadas, respectivamente, de 400 a.C. e 50 d.C., são consideradas os exemplos mais antigos de EaD que se tem registro. (26)

Depois destas, já no século XV, o primeiro avanço tecnológico para a EaD foi a invenção da imprensa de Gutemberg, que possibilitou a difusão em larga escala da palavra escrita. ${ }^{26}$ 
Com o surgimento do serviço postal na Europa, no final do século XVIII, surgiram também as primeiras iniciativas de educação por correspondência, que foi o modelo predominante até meados do século $X X$, onde estas tecnologias começaram a ser combinadas com outras que surgiram, como o telefone. ${ }^{25}$

A EaD pode ser dividida em cinco gerações de acordo com as tecnologias utilizadas em suas diferentes épocas, a partir de 1880, quando houve a ampliação das redes ferroviárias da Europa, o que possibilitou a obtenção de instrução por um professor à distância. ${ }^{24}$

\section{A primeira geração da EaD}

Aqui as correspondências eram a tecnologia utilizada, com o intuito de alcançar as pessoas que não poderiam estudar de outra forma, como por exemplo as mulheres, que não tinham acesso às instituições de ensino por conta da cultura da época. Foi ofertada pela primeira vez no ensino superior pelo Chautauqua Correspondence College que, em 1883, recebeu autorização do estado de Nova York para conceder diploma de bacharel para seus estudantes. ${ }^{24}$

A primeira instituição de ensino a oferecer cursos não presenciais no Brasil foi o Instituto Monitor, inaugurado em 1934, que oferecia aos alunos acesso a folhetos e esquemas de aulas por meio de correspondência. ${ }^{26}$

\section{A segunda geração da EaD}

Com a popularização do rádio, no início do século $X X$, muitos educadores ficaram otimistas com a possibilidade de sua utilização nos cursos de EaD. Em 1925, a Universidade Estadual de lowa, ainda com uma programação amadora, começou a oferecer cursos transmitidos através de uma emissora educacional de rádio. ${ }^{26}$

No ano de 1934, essa mesma instituição de ensino, com o apoio financeiro da Fundação Ford, começou a transmitir conteúdos educacionais através da TV. Devido 
ao seu êxito, em 1972, uma lei federal americana exigiu que todas as TVs a cabo tivessem, pelo menos, um canal educativo, que foram intitulados Telecursos. A maioria desses cursos utilizava também materiais impressos, tais como livros didáticos, guias de estudo e etc. ${ }^{25}$

Muitos projetos de EaD foram realizados com o uso do rádio no Brasil. Como exemplo podemos o Projeto Minerva, que disponibilizou principalmente no meio rural, materiais e programas, com o intuito de reduzir as barreiras para a formação existentes para os moradores do campo. ${ }^{26}$

Em 1970 foi inaugurada a Fundação Roberto Marinho, que passou a oferecer cursos de ensino fundamental e médio no modelo Teleducação, que se tornou viável graças a popularização dos aparelhos de TV no país. Em 1978, em parceria com a Fundação Padre Anchieta, foi desenvolvido o Telecurso $2^{\circ}$ grau que, além dos programas de TV, também fazia uso de materiais impressos para a formação de nível médio. Nesses mesmos moldes, em 1995, surgiu o Telecurso 2000.26

\section{A terceira geração da EaD.}

No final dos anos 1960 e começo dos anos 1970 surgiram as Universidades Abertas, que tiveram como suas principais experiências a Universidade Aberta da Grã-Bretanha e o Projeto AIM da Universidade de Wisconsin - EUA, que utilizavam áudio, vídeo e correspondência com orientação face a face baseada na abordagem sistêmica. ${ }^{24}$

Esse conceito começou a se estabelecer no Brasil quando o Conselho Federal de Educação propôs em parceria com especialistas do MEC, o documento "Ensino à Distância: uma opção", que levantava a EaD como alternativa para a democratização de oportunidades, pois esta é citada como dependente de acesso, permanência e qualidade de ensino. ${ }^{27}$ 


\section{A quarta geração da EaD}

Iniciou-se nos anos 1980 e foi baseada em áudio e videoconferência. Essas abordagens, que eram utilizadas por grupos de pessoas, aproximava mais a EaD do ensino tradicional ofertado pelos cursos presenciais. Essa característica atraiu um maior número de educadores do que os modelos usados anteriormente. As primeiras iniciativas utilizaram a áudio conferência através de linhas telefônicas, o que possibilitava aos estudantes responderem e questionarem durante as aulas. ${ }^{24}$

Nos anos 1990, com os sinais de satélites sendo transmitidos diretamente para as casas e escolas se popularizou a videoconferência como ferramenta de ensino na EaD. Com esse tipo de comunicação bidirecional, os primeiros cursos de graduação realizados inteiramente por teleconferência começaram a ser difundidos. ${ }^{25}$

\section{A quinta geração da EaD}

Foi aqui o grande marco da utilização de computadores e internet como principal forma de comunicação. Com eles tornou-se possível que pessoas acessassem um mesmo documento de qualquer lugar, com qualquer equipamento e/ou sistema operacional. ${ }^{25}$

$\mathrm{Na}$ década de 1990, algumas universidades americanas começaram a desenvolver cursos de graduação completos on-line. O oferecimento de cursos em $\mathrm{EaD}$ on-line foi tão difundido nas universidades americanas que no final dos anos 1990, mais de $70 \%$ de suas universidades públicas e comunitárias ofereciam cursos de graduação nesse formato. ${ }^{24}$

No Brasil, a internet começou a ser utilizada como apoio à EaD com sua popularização, principalmente no meio universitário, no final dos anos 1990, assim, a interação passou a poder ser realizada de muitos para muitos. ${ }^{26}$

Aqui ainda nos encontramos, vivenciando o surgimento de novas tecnologias e ferramentas que, se bem utilizadas, podem tornar a EaD cada vez mais viável e 
popular, podendo oferecer cursos de qualidade rompendo barreiras que a distância física impõe.

\subsubsection{Leis brasileiras que regem a EaD nos cursos de pós-graduação}

\section{Leis}

Lei $n^{\circ}$ 9.394/1996 - foi a primeira lei a deliberar a respeito da EaD no Brasil. Incentiva o desenvolvimento e a veiculação de programas de ensino a distância, inclusive para a educação continuada. Estabelece, principalmente, que apenas instituições credenciadas possam oferecer essa modalidade de cursos e que estes deverão ser regulados pelo Ministério da Educação e Cultura (MEC) ${ }^{28}$

Lei $n^{\circ}$ 9.610/1998 - delibera sobre os direitos autorais. A respeito da EaD, devido a suas particularidades no que se refere a produção de conteúdo coletivo, gerou muitas discussões a esse respeito até os dias de hoje. ${ }^{29}$

Lei n 13.005/2014 - Aprova o Plano Nacional de Educação - PNE e dá outras providências. É o atual Plano Nacional de Educação, com vigência de 2014 a 2024, preconiza que ao final do decênio o Brasil deverá formar 60 mil mestres e 25 mil doutores por ano, e contará com a EaD para atingir essa meta. ${ }^{30}$

Lei $n^{0} 13.620 / 2018$ - Institui o dia 27 de novembro como o Dia Nacional de Educação a Distância. ${ }^{31}$

\section{Decretos}

Decreto $n^{\circ}$ 8.752/2016 - Dispõe sobre a Política Nacional de Formação dos Profissionais da Educação Básica. Essa formação foi idealizada na modalidade EaD. ${ }^{32}$

Decreto $n^{\circ}$ 9.057/2017 - Regulamenta o art. 80 da Lei $n^{\circ}$ 9.394, de 20 de dezembro de 1996, que estabelece as diretrizes e bases da educação nacional. A 
partir deste, as instituições de ensino superior podem ampliar a oferta de cursos superiores de graduação e pós-graduação a distância. Entre os principais pontos, estão a criação de polos de EaD pelas próprias instituições e o credenciamento de instituições na modalidade EaD sem precisar oferecer ou ser credenciado para cursos presenciais. $^{33}$

Decreto $n^{\circ}$ 9.235/2017. Dispõe sobre o exercício das funções de regulação, supervisão e avaliação das instituições de educação superior (IES) e dos cursos superiores de graduação e de pós-graduação lato sensu, nas modalidades presencial e a distância, no sistema federal de ensino. Essa disposição procura promover maior acesso, sem perder a qualidade dos cursos estimulando a diversidade de ideias e de concepções. $^{34}$

\section{Resoluções}

Resolução n 3/2012-Conselho Nacional de Educação (CNE)/Conselho Pleno (CP) - Implementa o Programa Emergencial de Segunda Licenciatura para Professores ativos na Educação Básica Pública a ser coordenada pelo MEC, inserindo a educação a distância. ${ }^{35}$

Resolução n 1/2016-CNE/Câmara Estadual de Educação (CES) - Estabelece Diretrizes e Normas nacionais para a oferta de programas e cursos de educação superior na modalidade a distância. ${ }^{36}$

Resolução n 1/2018-CNE/CES - Estabelece diretrizes e normas para a oferta de cursos de pós-graduação lato sensu (cursos de especialização), no que se refere ao Sistema Federal de Educação Superior, inclusive sobre sua oferta na modalidade EaD.

\section{Portarias}

Portaria Normativa $n^{\circ} 2 / 2007-M E C$ - Dispõe sobre procedimentos de regulação e avaliação da educação superior na modalidade a distância. ${ }^{37}$ 
Portaria n 90/ 2019-Coordenação de Aperfeiçoamento de Pessoal de Nível Superior (CAPES) - Regulamenta os programas de pós-graduação stricto sensu na modalidade de educação a distância. ${ }^{38}$

\subsection{Cursos lato sensu}

Os cursos de pós-graduação lato sensu (também conhecidos como cursos de especialização ou ainda MBA - Master Business Administration), são voltados para pessoas que possuem diploma de graduação e que estão dentro dos parâmetros exigidos pelas instituições de ensino que os ofertam. ${ }^{39}$

Têm por objetivo complementar a formação acadêmica, aprimorar a atuação do profissional no mercado de trabalho e aperfeiçoar o atendimento de demandas técnicas, com o objetivo final de promover o desenvolvimento do país. Para isso deve focar na atualização, incorporando competências técnicas e desenvolvendo novos perfis profissionais. ${ }^{39}$

Podem ser ofertados por instituições credenciadas, todavia, preenchendo esse requisito, o curso em si, não precisa de credenciamento. O corpo docente deve ser constituído por, no mínimo, 50\% de professores mestres ou doutores, obtido em programa de pós-graduação stricto sensu reconhecido. Os demais devem possuir, minimamente, formação em nível de especialização. ${ }^{40}$

Devem ter duração mínima de 360 horas, somado ao tempo de estudo individual e ao destinado à elaboração de monografia ou trabalho de conclusão de curso. 40

O curso lato sensu ofertado na modalidade a distância só poderá ser oferecido por instituições credenciadas pela União, conforme o disposto no $\S 1^{\circ}$ do art. 80 da Lei 9.394, de 1996. Apesar de serem cursados a distância, estes deverão incluir provas e defesa de monografia ou trabalho de conclusão de curso presenciais. ${ }^{28,40}$

Por fim, os estudantes devem obter aproveitamento de acordo com 0 estabelecido no projeto pedagógico e frequência mínima de $75 \%{ }^{40}$ 


$$
\begin{array}{r}
\text { Referencial Teórico } \\
\text { Pedagógico }
\end{array}
$$




\section{REFERENCIAL TEÓRICO PEDAGÓGICO}

A busca pelo referencial teórico pedagógico para a elaboração dessa pesquisa foi direcionada para teorias pedagógicas que fundamentassem o processo de ensino e aprendizagem e que, ao mesmo tempo, incorporassem o significado que o uso das TICs tem para a modalidade de EaD, visto que, podemos perceber ao analisarmos seu histórico, que o advento de sua expansão exponencial está intimamente ligado aos avanços dessas tecnologias.

Assim, após análise, a teoria sócio-interacionista de Vygotsky se mostrou adequada para a discussão desse estudo, pois sua questão central é sobre a aquisição do conhecimento pela relação do sujeito com o meio. Nessa teoria o sujeito é interativo ao passo que adquire conhecimento a partir de trocas intra e interpessoais e de troca com o meio. ${ }^{41}$

Lev S. Vygotsky (1896-1934) foi um teórico multidisciplinar, formou-se em direito e literatura e depois foi um estudioso profundo em medicina. Focou seus estudos no substrato material do desenvolvimento psicológico, especificamente no cérebro, tendo realizado estudo sobre lesões cerebrais, perturbações da linguagem e organizações de funções psicológicas em condições normais e patológicas. Seus estudos foram aprofundados por estudiosos da neuropsicologia. Assim, suas proposições contemplaram que o ser humano, como membro de uma espécie biológica, só se desenvolve no interior de um grupo cultural. ${ }^{42}$

Durante o seu desenvolvimento. o indivíduo internaliza formas culturais de comportamento, num processo em que as atividades externas, funções interpessoais, transformam-se em atividades internas, intrapsicológicas ${ }^{41}$. Dessa forma, estamos mudando nossa forma de comunicação e de relacionamento interpessoal dada a massificação das TICs que possibilitaram a interação de grande parte dos brasileiros em redes sociais como Facebook e Instagram, ao uso de aplicativos de mensagens como o WhatsApp para comunicação e ao uso de plataforma de compartilhamento de vídeos como o YouTube, que pode ser usado para além da diversão, mas também para disseminar conhecimento e aprender. 
Para Vygotsky, a ênfase nos processos sócio-históricos de aprendizado, inclui a interdependência dos indivíduos envolvidos no processo. O papel do professor, nesse contexto, é ajudar o estudante a se desenvolver intelectualmente, pois enquanto aprende e se relaciona com outras pessoas, mais se desenvolve mentalmente e no âmbito das relações humanas. ${ }^{43}$

Esse conceito mostra que o aprendizado na EaD pode ser muito rico, pois proporciona que pessoas com experiências singulares, adquiridas em ambientes diversos, possam se relacionar em um ambiente educacional de discussão e de troca, o que proporciona que os estudantes tenham uma vivência mais ampla nessa modalidade de curso.

Assim, as proposições do sócio-interacionismo podem ser consideradas absolutamente compatíveis com a EaD, em função da qualidade de relacionamentos que ela proporciona, inclusive a da interação tutorial, de enorme importância para este tipo de aprendizagem. O conhecimento deixa de ser consumido e assimilado passivamente, passando a ser produto de processos de elaboração e construção. ${ }^{44}$

No que diz respeito às questões de aprendizagem, segundo Vygotsky, podemos refletir que os ambientes de aprendizagem em EAD se assemelham ao funcionamento da mente humana em sua característica não linear, o que pode estreitar o distanciamento entre o conhecimento e o ser humano, já que o contato do homem com o conhecimento também ocorre de forma não linear. ${ }^{45,46}$

Sendo assim, a teoria sócio-interacionista de Vygotsky nos mostra que a EaD está apta como modalidade de ensino aprendizagem, visto que proporciona com o uso das TICs a interação social entre os atores envolvidos e também, através delas, se insere na cultura estabelecida com o seu desenvolvimento e massificação. 


\section{Percurso Metodológico}




\section{PERCURSO METODOLÓGICO}

Este capítulo apresenta o percurso metodológico que foi utilizado neste estudo para alcançar os objetivos propostos.

\subsection{Delineamento do estudo}

Com base no tema e objetivos propostos para o estudo, optou-se pela pesquisa qualitativa de caráter exploratório descritivo.

A abordagem qualitativa parte do fundamento de que há uma relação dinâmica entre o mundo real e o sujeito, uma interdependência viva entre o sujeito e o objeto, um vínculo indissociável entre o mundo objetivo e a subjetividade do sujeito. ${ }^{47}$

A pesquisa qualitativa é utilizada para responder a questionamentos particulares. Pode também ser multimetodológica, envolvendo abordagens interpretativas e naturalísticas dos assuntos. Assim, o pesquisador qualitativo estuda coisas em seu ambiente natural, procurando as interpretar segundo o significado que as pessoas as atribuem. ${ }^{48}$

As pesquisas qualitativas também são capazes de incorporar significado e a intencionalidade como parte inseparável dos atos, das relações, e das estruturas sociais, tanto no seu advento quanto na sua transformação, como construções humanas e significativas ${ }^{48}$. Dessa forma, busca compreender experiências de vida a partir das perspectivas dos sujeitos que a vivenciam, com seus respectivos valores, atitudes, crenças, emoções, sentimentos e desejos, valorizando as interações relacionais. ${ }^{49}$

A abordagem descritiva é praticada quando se pretende buscar o conhecimento de determinadas informações e também por ser um método capaz de descrever percepções, fatos e fenômenos de determinada realidade. 


\subsection{Locais do estudo}

O estudo foi realizado em locais designados pelos professores que participaram da pesquisa, sendo que para alguns a escolha foi a instituição de ensino onde trabalham e, para outros, a entrevista foi feita por meio de vídeo-chamada em horário e local oportuno para os mesmos.

$\mathrm{Na}$ concepção desse estudo, a pesquisadora tinha o objetivo de entrevistar sujeitos de todas as regiões do Brasil, porém ao fazer a pesquisa por cursos e instituições, ficou claro que a enorme maioria das instituições de ensino que oferecem cursos de pós-graduação lato sensu nas áreas da saúde têm suas sedes no sul e sudeste do país, com polos em diversas cidades espalhadas pelo território nacional. Assim, mesmo os sujeitos da pesquisa estando concentrados nas regiões sul e sudeste, a abrangência de suas atuações é nacional.

\subsection{Critério de inclusão}

$\diamond$ Ser professor ou coordenador de cursos lato sensu nas áreas da saúde oferecidos na modalidade de EaD.

$\diamond \quad$ Ter participado da construção ou desenvolvimento destes cursos.

$\checkmark$ Ter concordado e, portanto, assinado o Termo de Consentimento Livre e Esclarecido (TCLE) (apêndice 1)

\subsection{Descrição dos instrumentos e procedimentos da coleta de dados}

\subsubsection{Instrumentos para coleta de dados.}

A pesquisadora utilizou entrevista semiestruturada com questões norteadoras para o alcance dos objetivos, sendo estas:

1. Como o senhor (a) percebe a Educação a Distância, hoje, nos cursos lato sensu das áreas da saúde? 
2. Para o senhor (a), qual a relevância da Educação a Distância para os cursos lato sensu das áreas da saúde?

3. Diante disso, qual o papel das metodologias de ensino, na construção e desenvolvimento dos cursos lato sensu das áreas da saúde?

Também foi utilizado um formulário sobre as ferramentas e metodologias de ensino utilizadas nos referidos cursos (apêndice 2).

\subsubsection{Sujeitos da pesquisa}

A busca pelos sujeitos da pesquisa foi feita utilizando o método de amostragem por bola de neve. Este método pressupõe que há uma ligação entre os sujeitos da pesquisa dado pela característica buscada, isto é, os sujeitos da pesquisa são capazes de identificar potenciais membros da mesma. ${ }^{50}$

A pesquisadora buscou profissionais que se encaixassem no critério de inclusão da pesquisa em redes sociais (Linkedln e Facebook) através de um post convite para participar do estudo. Essa escolha foi feita porque a pesquisadora tinha conhecimento de que existia pessoas que se adequavam nos critérios de inclusão em sua rede de contatos.

Alguns profissionais que responderam ao convite se encaixaram nos critérios de inclusão. De acordo com o método bola de neve, esses sujeitos são chamados de semente da amostra e são considerados a onda zero. Quando foi solicitado pela pesquisadora, estes indicaram sujeitos que acreditavam se encaixar nos critérios (segunda onda) da pesquisa e assim sucessivamente. ${ }^{51}$

A amostra contou com 9 participantes, sendo 6 enfermeiros, 1 médico, 1 advogado e 1 fisioterapeuta. Estes atuavam ou haviam atuado como professores, coordenadores, desenvolvedores de conteúdo e tutores. Mesmo com o método bola de neve estes profissionais retornaram experiências em 7 instituições de ensino diferentes. 


\subsubsection{Procedimento de coleta de dados}

Após esse levantamento a pesquisadora entrou em contato por e-mail com os sujeitos que responderam ao convite. Após o primeiro contato (a conversa poderia continuar por e-mail ou WhatsApp), a pesquisadora explicava os detalhes da pesquisa e, em caso de satisfação dos critérios de inclusão, havia dois caminhos possíveis:

$\diamond \quad$ Um encontro presencial era marcado, onde a pesquisadora entregava uma cópia do TCLE, tirava as possíveis dúvidas e pegava a assinatura em outra, entregava uma cópia do formulário (que também era enviado por e-mail para facilitar o preenchimento e a devolução, e a entrevista era realizada com o gravador de voz do smartphone da pesquisadora. Em alguns dias o participante retornava o formulário via e-mail.

$\diamond \quad$ O participante sinalizava que um encontro virtual seria mais apropriado. Então a pesquisadora enviava o formulário e o TCLE por e-mail e o horário para a entrevista era marcado. No horário pré-definido a chamada de vídeo era realizada pelo smartphone, as dúvidas sanadas e a entrevista gravada pelo gravador de voz do computador, assegurando que a imagem do participante não seria gravada. Após alguns dias o participante retornava o formulário via e-mail.

Essas entrevistas foram agendadas de acordo com a disponibilidade dos mesmos, em local, data e horário convenientes para eles.

Todas as entrevistas foram feitas após a leitura e assinatura das duas vias do Termo de Consentimento Livre e Esclarecido, em locais reservados indicados pelos coordenadores, preservando a privacidade e acolhimento dos mesmos.

Ao utilizar vários métodos de coleta de dados, o pesquisador pode recorrer a várias perspectivas sobre a mesma situação, obtendo informações de diferente natureza e proceder, podendo comparar posteriormente essas informações. Esse método permite uma maior confiabilidade nos dados recolhidos.

Os participantes foram identificados por números para que o anonimato fosse garantido e as instituições onde os mesmos atuam foram mantidas em sigilo, inclusive na transcrição das entrevistas. 
As entrevistas foram transcritas, lidas e categorizadas. A partir dessas categorias a pesquisadora identificou o papel que as metodologias de ensino têm na construção e desenvolvimento dos cursos lato sensu que foram o ponto de partida das discussões desse estudo.

Os formulários trouxeram informações a respeito das ferramentas mais utilizadas, como eram utilizadas e com qual objetivo. Essas informações foram úteis para identificar qual o papel das metodologias de ensino frente as ferramentas disponíveis.

\subsection{Análise dos dados}

A análise das entrevistas e formulários foi realizada mediante a técnica de análise de conteúdo. Nessa técnica, o pesquisador descreve e interpreta o conteúdo das mensagens, buscando dar respostas à problemática que motivou a pesquisa e, assim, corroborando com a produção de conhecimento teórico. Quanto aos formulários, estes foram analisados com foco nas metodologias de ensino em EaD, em como são utilizadas de acordo com as ferramentas disponíveis para o processo de ensino aprendizagem de cada curso. ${ }^{52}$

Após a análise do conteúdo, foi feita uma categorização/classificação dos achados. As categorias consideraram o material analisado em consonância com os objetivos do estudo.

Para que o estudo seja relevante e consistente, foi feita uma leitura compreensiva do material, de forma exaustiva, para que fossem bem escolhidas e definidas as unidades de análise e as categorias a serem consideradas. Em uma abordagem qualitativa também se faz necessária a produção de inferência, ou seja, procurar além do que foi escrito e/ou falado, para o alcance da interpretação das informações. ${ }^{52}$ 


\subsection{Aspectos Éticos da Pesquisa}

A Ética revela-se como elemento essencial e norteador do exercício profissional, bem como o desenvolvimento de pesquisas científicas que envolvam seres humanos, portanto, esse estudo respeitou os aspectos ético-legais da Resolução n. ${ }^{\circ}$ 466/2012 do Conselho Nacional de Saúde (CNS), que versa sobre os aspectos éticos em pesquisas envolvendo seres humanos. ${ }^{53}$

O estudo foi submetido à apreciação do Comitê de Ética em Pesquisa da Escola de Enfermagem da USP (CEP/EEUSP) e aprovado sob o protocolo 2.384.492. Os dados foram coletados somente após autorização deste Comitê. (apêndice 3) 
Análíse e díscussão dos dados 


\section{Formulários}

Os formulários foram desenvolvidos tanto para trazer ao conhecimento as ferramentas que são mais utilizadas nos cursos lato sensu na modalidade EaD das áreas da saúde, como para evidenciar quais metodologias são utilizadas para trabalhar com essas ferramentas e quais os objetivos pretendidos com o uso das ferramentas e dos métodos.

A pesquisadora fez uma extensa procura em site de busca (Google) para encontrar todas as ferramentas disponíveis nas plataformas de cursos de EaD, e também as que não estavam necessariamente dentro das plataformas, mas eram utilizadas como apoio no processo de ensino aprendizagem dessa modalidade.

A pesquisa retornou as seguintes modalidades que foram disponibilizadas no formulário, juntamente com a opção "Outros", onde os participantes poderiam incluir alguma ferramenta não levantada na pesquisa, são elas:

\section{Fórum}

Citado em $67 \%$ dos formulários. É uma área da plataforma virtual no qual o estudante dos cursos em EAD tem a oportunidade de se aprofundar nos conteúdos abordados nas aulas, tirar dúvidas, debater assuntos ligados às disciplinas e se relacionar com outros estudantes. É uma ferramenta utilizada para desenvolver o raciocínio crítico, maturar ideias e posicionamentos, compreender conceitos científicos, acima de tudo, compartilhar conhecimento. ${ }^{55}$

Segundo os professores, usado principalmente com o intuito de promover a Interação entre os atores envolvidos no processo de ensino aprendizagem, pois proporciona a troca de informações, compartilhamento de dúvidas, discussão e troca de experiência, com o objetivo de solucionar problemas enquanto desenvolvem o pensamento crítico. Essa é uma estratégia que também permite que o professor e/ou tutor avaliem, tanto os estudantes, quanto o desenvolvimento do curso. 
A aprendizagem com ênfase nos processos sócio-históricos inclui a interdependência dos indivíduos envolvidos no processo. O papel do professor, nesse contexto, é auxiliar o aluno a desenvolver-se intelectualmente, pois enquanto aprende e se relaciona com outras pessoas, mais se desenvolve mentalmente e no âmbito das relações humanas. ${ }^{44}$

\section{Blog}

Não foi citado em nenhum formulário. São páginas da internet onde diversos conteúdos são publicados frequentemente, como textos, imagens, músicas ou vídeos. Podem ser dedicados a um assunto específico como ser de âmbito bastante geral, mantidos por uma ou várias pessoas e normalmente disponibilizando espaço para os comentários dos seus leitores. ${ }^{56}$

\section{Biblioteca digital}

Citado em $55 \%$ dos formulários. Sua informação existe apenas na forma digital, Desta forma, não contém livros na forma convencional e a informação pode ser acessada em locais específicos e remotamente. A grande vantagem da informação digitalizada é que ela pode ser compartilhada instantânea e facilmente, com um custo relativamente baixo. ${ }^{57}$

Ferramenta utilizada com o objetivo de estimular a busca pelo conhecimento através do enriquecimento teórico, pois fornece acesso a diferentes materiais relacionados ao tema do curso de forma mais direta e de acordo com a proposta pedagógica.

\section{Votador de dúvidas}

Não foi citado em nenhum formulário. É utilizado como um repositório de dúvidas onde o estudante visualiza as dúvidas que já foram postadas e vota nas que 
também tem ou, na ausência de dúvida equivalente, faz sua postagem. Essa ferramenta possibilita uma organização melhor das dúvidas, além de mostrar para os coordenadores quais os questionamentos mais recorrentes, para que, assim, estratégias possam ser desenvolvidas para resolvê-las.

\section{Vídeo aulas}

Citado em $78 \%$ dos formulários. Aulas preparadas para serem disponibilizadas e assistidas nos cursos no formato EaD.

Utilizada com o objetivo de aproximar a figura do professor dos estudantes, enfatizando os conteúdos e complementando o material didático com apresentações breves e objetivas, em uma reflexão direcionada aos estudantes que acabam por abraçar diversos estilos de aprendizagem.

\section{Áudio-conferência}

Não foi citado em nenhum formulário. Momento de encontro síncrono entre participantes para falar sobre determinado assunto, utilizando conexão de áudio.

\section{Vídeo-conferência}

Citado em 22\% dos formulários. Momento de encontro síncrono entre participantes para falar sobre determinado assunto, utilizando conexão via vídeo.

Momento de interação direta entre docente e discentes, onde estes podem discutir e tirar as dúvidas e discutir os temas das unidades de ensino.

\section{Games}


Citado em $33 \%$ dos formulários. Jogos interativos para estimular, treinar e avaliar a fixação do conteúdo.

Os games são utilizados frequentemente com o objetivo desde avaliar a assimilação e fixação do conteúdo, ao mesmo tempo dando uma devolutiva para que o aluno perceba seus pontos fortes e fracos. Também pode ser usado para simular experiência prática em ambiente virtual que mimetiza a realidade.

\section{Ferramentas de edição compartilhada de documentos on-line}

Citado em $22 \%$ dos formulários. Utilizadas para a produção em grupo de material escrito.

Utilizado para promover a interação entre os estudantes ao mesmo tempo que direciona a busca do conteúdo ao passo que é solicitado aos alunos que desenvolvam temas pré-estabelecidos na construção e desenvolvimento do curso.

Assim, segundo Vygotsky, o professor precisa dar atenção às relação, promovendo os espaços sociais, a fim de viabilizar a comunicação e facilitar o convívio em grupo e sociedade. Considerando ainda que aprendizagem se dê pelo processo de socialização e pela maturação orgânica e encontra-se dependente dos processos de internalização (interiorização) - que envolve transformação dos fenômenos sociais em fenômenos psicológicos. ${ }^{44}$

\section{Podcasts}

Não foi citado em nenhum formulário. Programas de discussões temáticas feitas por especialistas nos assuntos determinados.

\section{Plataforma de compartilhamento de vídeos}

Citado em $33 \%$ dos formulários. Locais onde vídeos podem ser compartilhados 
e acessados de maneira oportuna pelos estudantes. Também pode ser considerada como material de apoio, pois seus vídeos são liberados para a comunidade virtual.

Empregado como mais uma alternativa para a fixação de conteúdo, diversificando o material de estudo, com indicação de fontes complementares (vídeos e/ou documentários) a respeito do tema estudado, com o respaldo dos desenvolvedores do curso. Essa metodologia é eficiente na promoção do enriquecimento do conteúdo teórico-científico, pois, estimulando o uso de outras fontes de conhecimento é possível instigar a reflexão sobre o tema estudado.

\section{Apresentações eletrônicas}

Citado em $33 \%$ dos formulários. Software onde os estudantes podem preparar e apresentar remotamente as tarefas solicitadas nos cursos.

Usada para apresentar uma versão condensada, ou seja, em tópicos com palavras-chave e esquemas para auxiliar os estudantes na compreensão do tema proposto. Também pode ser utilizada para os estudantes compartilharem suas tarefas no estilo de seminário, que pode ser outra metodologia de ensino empregada para exercitar a busca do conhecimento.

\section{Realidade Virtual}

Não foi citado em nenhum formulário. É uma tecnologia cujo mecanismo é aplicado a uma interface que conecta os usuários, utilizando um sistema informatizado, para construir uma plataforma realista, proporcionando ao visitante a sensação de que o que se está vendo é parte do real. ${ }^{58}$

\section{Realidade Aumentada}

Não foi citado em nenhum formulário. É um elemento que dispõe de uma visão 
diferente da realidade. Consiste na combinação de elementos do ambiente real com elementos de um ambiente virtual que são criados em três dimensões, combinando esses dois elementos em tempo real. ${ }^{59}$

\section{Ambiente Virtual de Aprendizagem}

Citado em 33\% dos formulários. Se caracterizam como espaços que organizam recursos e ferramentas que englobam elementos técnicos - como computadores, softwares e servidores, entre outros; humanos - estudantes, professores e demais profissionais envolvidos no processo de ensino e aprendizagem; e suas relações troca de e-mails, discussões em fóruns e listas, construção coletiva de texto, entre outros. $^{60}$

Considerado a representação de "escola" na EaD. Utilizado para concentrar os conteúdos dos cursos, ser um ambiente de estudo equivalente à sala de aula, como um local formal e de registro de atividades. Com suas ferramentas promove a interação síncrona e assíncrona entre os envolvidos no processo de ensino e aprendizagem.

\section{Questionário}

Citado em 33\% dos formulários. Como o nome diz, é um questionário, só que virtual. Utilizado como uma forma de avaliação nos cursos de EaD.

Basicamente utilizado para avaliar o quanto os estudantes entenderam o conteúdo compartilhado e desenvolvido nas outras atividades do curso.

\section{Diário de bordo}

Não foi citado em nenhum formulário. Documento utilizado para registrar o desenvolvimento de uma atividade didática. 
Wiki

Não foi citado em nenhum formulário. Websites colaborativos, cujo conteúdo pode ser modificado pelos usuários. ${ }^{61}$

\section{Glossário}

Citado em $10 \%$ dos formulários. Dicionário de termos utilizados nos materiais dos cursos.

Pode ser usado para indicar itens para a busca, o que acaba auxiliando o estudante na compreensão, escrita e utilização dos termos técnicos científicos.

\section{Tarefas}

Citado em 33\% dos formulários. Espaço dedicado à postagem das tarefas solicitadas nos cursos. Pode ser uma apresentação dirigida ou uma resenha, por exemplo.

Construção de resenhas, projetos e manuscritos com foco no conteúdo estudado, com o propósito de estimular o estudante a resolver problemas que encontrarão no ambiente profissional. Também pode ser usado como ferramenta de avaliação, dependendo da metodologia escolhida.

\section{Material impresso}

Citado em $44 \%$ dos formulários. Material de apoio ofertado impresso para o estudante.

Material base do curso, idealizado para ser próprio do mesmo, contendo as 
informações, referências e bibliografia básicas do curso. Pode conter as informações iniciais para o uso da plataforma de ensino e também o material autoral do curso.

\section{Tutorial}

Citado em 33\% dos formulários. Ensina a realizar uma tarefa específica. Pode ser um texto, apresentação, esquemas, esquemas com figuras, vídeos e etc.

Ferramenta utilizada para orientar os estudantes sobre o desenvolvimento do curso e como navegar na plataforma, esclarecendo os caminhos da aprendizagem.

\section{Entrevistas}

A leitura das falas, orientada pelo método de análise de conteúdo, possibilitou que suas essências fossem levantadas, permitindo a categorização das falas consonantes.

Ao categorizar as falas, estas nos mostraram que o discurso dos participantes da pesquisa traz um pensamento coletivo a respeito da temática do estudo, evidenciando assim, que nossa amostra foi adequada para chegar a um consenso a respeito do foco da pesquisa.

Nesse estudo, 4 categorias emergiram durante a leitura compreensiva das falas. São elas: Reflexões acerca dos cursos oferecidos na modalidade EaD; Acesso aos cursos de especialização; O papel das Tecnologias de Informação e comunicação; e A importância das metodologias de ensino para os cursos lato sensu das áreas da saúde.

\section{Reflexões acerca dos cursos na modalidade EaD}

Um fato que ficou claro durante o desenvolvimento desse estudo é que o assunto EaD traz muitas discussões e opiniões diferentes, principalmente quando 
estamos focando nos cursos das áreas da saúde. Portanto, as reflexões a respeito desse tema tiveram um papel de destaque durante as entrevistas.

A princípio, a facilidade do acesso, tanto no que diz respeito a tempo, flexibilidade de horário e investimento, se sobressaem como pontos positivos nessas reflexões, como nas falas a seguir:

"Eu vejo como uma oportunidade de acesso. Eu coloco o ensino à distância como uma oportunidade de alcançar o maior número de pessoas e que, apesar disso o curso não vai perder qualidade." (8)

"Quando bem utilizado, é uma ferramenta potente de acesso à educação em todos os níveis, ensino básico, médio, educação a nível de formação..." (8)

"Eu acredito muito no EaD. Eu acho que é uma oportunidade para garantir profissionais especializados." (3)

"Ele (o estudante) se dedica àquilo de uma forma muito mais abrangente do que ele se dedicaria se tivesse que ir para uma sala de aula dentro de um horário cartesiano, tendo que responder chamada, tendo que ser penalizado por não poder ir..." (5)

"O ensino à distância tem sido mais uma opção de mediação de conhecimento, de oportunidade a pessoas que não teriam acesso ao ensino formal e tradicional." (8)

"embora tenhamos um processo de massificação através das grandes holdings de educação que a gente vê dominando o mercado, quando bem utilizado (o EaD), eu vejo como algo muito positivo dentro do contexto da educação brasileira." (8)

"quando a gente pensa em um conceito, em um modelo de educação, pensado na realidade atual, o EaD, pra mim, é mais eficiente e, se as faculdades trabalharem isso melhor, pode ser mais vantajoso para o aluno e para o professor." (5)

Podemos perceber nesses discursos que há uma abertura no que tange às oportunidades que se expandiram para as pessoas poderem se formar e se especializar. Essas reflexões também são impulsionadas pela visão que os professores têm da dificuldade que os profissionais de saúde no Brasil vivenciam, devido as características regionais, culturais e socioeconômicas que nossa população enfrenta. 
Outra fala levantada, que, de certa forma, traz um primeiro contraponto durante as reflexões acerca da EaD é a garantia da qualidade.

“Quando bem aplicado só tem bons frutos." (4)

"Eu tenho algumas experiências em formação para o SUS bastante exitosas utilizando o ensino à distância!” (8)

"eu acredito na qualidade dos profissionais que formamos, dentro da proposta que a gente desenvolvia." (8)

"a gente tá tendo uma oferta muito grande e a concorrência, nisso em especial, está sendo positiva. Porque como tem uma oferta grande, obriga as instituições a buscar sempre uma qualidade maior em seus cursos, procurar melhorar em termos de conteúdo para que ele consiga se sobressair no mercado..." (9)

"conhecimento em si, independente se no papel ou de forma eletrônica, é bem-vindo, desde que seja com qualidade, com embasamento, com evidência científica, eu acho que é bem saudável." (6)

As colocações mostram que a preocupação com a qualidade dos cursos oferecidos e dos profissionais que serão formados é bem latente. Até certo ponto, vemos inclusive uma preocupação ética com os estudantes e suas ações após a formação.

Essa preocupação com os estudantes também fica evidente quando os professores mostram que estão atentos à postura dos mesmos no decorrer do curso, principalmente no que diz respeito à participação e interação destes com os outros atores envolvidos.

"o aluno de EaD, me parece que ele está mais focado que o aluno em sala presencial." (5)

"o EaD ajuda nisso, facilita que as pessoas discutam. Eu, por exemplo, uso muito a plataforma do Moodle na faculdade (...), e você tem que ver a riqueza das discussões!" (5)

“O EaD, na minha opinião, faz com que as pessoas sejam mais livres para interagir e opinar na resposta dos outros, nos propiciando um ambiente de discussão." (5)

"Eu vejo muito mais interação no EaD que no ensino presencial. No ensino presencial eu estou elogiando a sua roupa, eu quero saber quanto foi o jogo e quero rir se o professor estiver com a braguilha aberta." (5) 
"o aluno quando vê ou ouve falar do conteúdo aprendido, lembra da experiência extraordinária que teve com o EAD e a tendência é que ele fique adepto como eu fiquei dessa metodologia." (1)

As falas também nos mostram que a aprovação dos alunos é uma preocupação real dos desenvolvedores dos cursos.

Outra reflexão que surge nos discursos é a respeito do papel do professor nessa modalidade de ensino que está mudando a forma de ensinar, aprender e buscar conhecimento e formação.

"eu gosto (do EaD), acho muito interessante, apesar da gente não ter aquele contato direto com o aluno, que nós, professores, gostamos tanto..." (9)

"Mesmo que você tenha o chat e o fórum, eu acho que a pessoa que intermedia esse processo é que faz com que se torne próximo do aluno $e$ que a aprendizagem tenha um significado real para aquela pessoa." (7)

“(no EaD) a instituição deixa de investir em estrutura besta, em quadro negro, por exemplo, e paga a hora do profissional qualificado, cobrando dele um curso bem feito, que é o que o aluno de EaD merece tanto quanto o aluno de sala de aula presencial." (5)

O professor percebe que seu papel e sua imagem estão mudando e isso pode causar muita estranheza para estes profissionais, porém, é perceptível que em alguns casos os eles se sentem seguros que, apesar da mudança, seu papel ainda é central no processo de ensino e aprendizagem.

O modo como estão sendo expostos a essa nova modalidade de ensino traz uma reflexão sobre as concepções pedagógicas apropriadas.

"antes da metodologia, é a concepção pedagógica que o docente tem. Ele vai ter uma concepção pedagógica tradicional ou uma concepção pedagógica crítica, independente da linha metodológica que ele vai seguir." (8)

"Quando ele tem uma concepção pedagógica crítica, vai se abrir um universo de metodologias pra utilizar em sala de aula." (8)

Por outro lado, a mudança que essa modalidade de ensino traz também preocupa os profissionais acerca de sua inserção no mercado de trabalho em 
transição.

"por outro lado, pensando como profissional, como professora, eu acho que restringe muito a nossa área de atuação, porque um professor conteudista, por exemplo, prepara o material e este só será revisado daqui a dois anos. Então você não consegue viver disso. Você trabalha uma vez, prepara o material, leva dois ou até três meses pra preparar o conteúdo de uma disciplina e recebe por aqueles três meses e não recebe mais. Então, pensando no profissional, não é bom. A perspectiva é ruim em termos financeiros." (9)

"Você tem um curso presencial de pós, com três ou quatro professores. Já no EaD só tem um, que é o tutor, talvezs um ou outro especialista na área (porque o tutor não precisa ser) que vai ficar num laboratório para tirar dúvidas, para uma aula presencial que seja. Então vai reduzir muito o campo de trabalho." (9)

Mesmo assim, há certa esperança de que, com a prioridade em oferecer cursos de alta qualidade, os educadores sejam valorizados e mais bem remunerados.

"A universidade pode vir a remunerar melhor o professor, fomentar melhor o mercado de educação e investir no que realmente deve, que é no bom profissional." (5)

"é um impacto grande para o profissional professor. Já pro aluno, eu acho que é uma vantagem tremenda, principalmente para aqueles que tem dificuldade de acesso." (9)

Há essa ideia que a EaD pode melhorar muito a possibilidade de crescimento pessoal e profissional que as pessoas precisam e procuram, porém, o receio de que as ferramentas estão sendo utilizadas de forma errada pode comprometer a qualidade do ensino:

“Eu vejo como uma extensão do curso presencial." (2)

"o que eu percebo é uma mimetização do ensino presencial, usando metodologias que já são falidas no ensino presencial.” (2)

"ele foi alterado, mas a forma como foi não acompanha as necessidades do ensino à distância." (2)

“o tutor muitas vezes não é o professor que tem uma expertise na área, ele é um professor que foi contratado como tutor, então, se o aluno tem uma dúvida que é da especialidade, ele não consegue sanar." (7) 
"A impressão que eu tenho é que alguns cursos acabam não cumprindo o seu papel de tornar as pessoas especialistas naquela área." (7)

Essas percepções fazem sentido, visto que muitos professores se inserem nessa modalidade de ensino sem estarem preparados e atualizados. Isso é percebido quando estes levantam a questão do uso de metodologias compatíveis com esse tipo de curso.

"se não houver uma forte implementação de metodologias adequadas no ensino virtual a gente vai cometer os mesmos erros que cometemos no ensino presencial, potencializado, porque o ensino presencial tem alguns ganhos que o ensino virtual não acompanha, como impressões, percepções docentes... muitas vezes você olha para um aluno em sala de aula e percebe que ele não tá entendendo, para e volta... no virtual, isso tende a se perder um pouco, dependendo de como você usa a ferramenta." (2)

"a minha preocupação ainda é na qualidade que se oferta nesses cursos." (4)

"Então muitas vezes a gente tem um custo diminuído quando você opta por um EaD, principalmente em formação do SUS, mas você também tem uma oneração por ter uma evasão muito alta." (8)

A diminuição de custos ao oferecer cursos em EaD são os grandes chamarizes para as instituições de ensino, porém, se a qualidade não estiver também na lista de prioridades destas, o curso pode incorrer no erro de não prezar pela adesão dos estudantes. Se isso acontecer, o investimento pode não compensar.

Apesar de todas essas questões, quando o este é bem planejado e os professores são apoiados em seu desenvolvimento, a experiência pode ser bem positiva para todos os envolvidos, como vemos nas falas a seguir:

"eu era contra e hoje eu sou completamente a favor." (1)

"Eu entrei nessa área com certo preconceito, mas hoje eu acho que o EAD na área da saúde já está equiparado com os cursos presenciais." (1)

"Precisa mudar um pouco a mentalidade na minha opinião, porque hoje ainda temos muito preconceito com o EaD." (5)

"As pessoas que criticam não têm o discernimento de que o EaD é tal qual uma dinâmica de sala de aula." (5) 
"o método do EaD é muito mal julgado, quando ele deveria ser observado sob um outro prisma, pois pode ser a solução para um o déficit educacional que a gente tem." (5)

"sala de aula, desde a Grécia antiga, é o professor, alunos e, no mais, uma lousa e um giz, foi o que evoluiu em 2.500 anos, por isso acredito que tenha essa resistência." (1)

É histórico que mudanças causam certo receio em seu período probatório e até depois, mas no que diz respeito a $\mathrm{EaD}$, já podemos perceber uma abertura no discurso dos professores e um reconhecimento do seu potencial, como vemos a seguir:

"eu acho que o ensino a distância vai crescer ainda mais, não apenas nas especializações, mas também nas graduações, como já é uma tendência." (4)

"nos cursos de pós-graduação, eu cito por exemplo a área da enfermagem do trabalho, em algumas instituições, já não tem turmas presenciais." (6)

"Então eu enxergo o curso em EaD como uma premissa de futuro para a educação, para quem quer estudar, pra quem precisa estudar e pra quem tem outras atribuições." (5)

"é esse esforço conjunto, essa compilação de várias ferramentas utilizadas ao mesmo tempo que vai potencializar o EaD e melhorar a qualidade da formação." (8)

"é uma tendência natural, tendo em vista que a tecnologia está aí para nos ajudar." (6)

"Os cursos de especialização em saúde, na minha opinião, caminham em uma direção adequada no EaD, que vem para fazer com que as pessoas consigam se especializar, para que tenhamos mais especialistas cuidando das pessoas." (5)

"as pessoas buscam o EaD hoje em dia mais para especialização do que para graduação. Porém eu acredito que a tendência é que as faculdades também acabem optando pela graduação em EaD” (5)

"os cursos presenciais vão ficar para trás, o EAD vai passar num futuro bem rápido e vai ser o método de ensino para especialização mais procurado por profissionais de saúde por vários motivos." (1) 
"eu acho que os cursos presenciais nunca vão terminar, porque mesmo a EaD tem um momento que precisa ter um encontro presencial, que eles precisam de um tutor." (9)

Apesar do crescimento da EaD no Brasil, não podemos decretar que o ensino presencial está fadado a desaparecer. Ele se encontra em um período de mudanças, sim, até porque, como estamos discutindo, a expansão das TICs está causando uma mudança cultural em nossa sociedade e o escopo da educação não estará de fora dessa mudança.

\section{Acesso aos cursos de especialização}

A EaD está entrando no mercado educacional primeiramente como a saída para uma significativa parcela dos profissionais ter a chance de se especializar e, apesar de estar entrando em praticamente todos os nichos que o mercado possui, sua massiva atuação ainda é na formação continuada.

Considerando as dificuldades enfrentadas por profissionais de saúde com relação ao acesso à formação continuada, os profissionais vêem a EAD como uma estratégia para a especialização frente as novas tecnologias e como uma inovação pedagógica no ensino lato sensu. ${ }^{62}$

"é uma possibilidade a mais de acesso a um maior número de pessoas de uma formação de qualidade com o uso de uma plataforma à distância." (8)

"antigamente esses cursos eram muito centralizados a um pequeno grupo. Hoje tem uma maior difusão do conhecimento. O mais importante é isso, você formar mais pessoas." (7)

"eu vejo como uma potencialidade, como um caminho pra levar formação para o maior número de pessoas possível." (8)

"realmente há pessoas que tem vontade de fazer uma pós-graduação e que não conseguiria fazer no presencial. Hoje consegue no EaD." (7)

"Eu vi uma reportagem que dizia que o número de alunos ingressando na graduação à distância cresceu 20-25\%, enquanto na graduação presencial diminuiu cerca de 10 \% em relação ao que era." (4) 
“(O EaD) facilita o acesso, sem dúvida alguma.” (4)

"A primeira vantagem que eu vejo é o acesso, porque a gente sabe que o nosso país é continental. A gente está muito confortável aqui na região sudeste, porque pra gente o acesso é muito fácil." (9)

O acesso aos cursos de especialização encontrava suas primeiras barreiras na escassez de tempo,

"uma fala recorrente do profissional da saúde hoje, é que ele tem o tempo escasso." (2)

"Tem muitas pessoas que param de estudar numa universidade cartesiana por conta da falta de tempo." (5)

"Eu vejo nos dados das universidades em que eu dou aula, que as pessoas que desistem dos cursos, não desistem por estarem desestimuladas e sim porque não conseguem chegar na aula." (5)

"as pessoas precisam trabalhar, precisam ter tempo, e muitas vezes isso não acontece." (4)

"Eu vejo que é uma nova tendência de mercado, de sobrevivência mesmo, num mundo em que as pessoas precisam saber muito, em pouco tempo e com menos idade." (4)

Os profissionais hoje têm muitas obrigações com horários de trabalho e rotina da vida pessoal. Estas pessoas também têm a pressão de estarem vivendo em um mundo extremamente competitivo, onde o conhecimento se expande em progressão geométrica, por isso precisam de tempo para fazer suas capacitações.

Diante disso, outro ponto nevrálgico para esses estudantes é encontrar uma brecha em sua rotina que se encaixe nos cursos presenciais para se dedicarem a cursos de especialização,

"uma fala recorrente do profissional da saúde hoje, é que ele tem o tempo escasso." (2)

"É uma fala recorrente em qualquer nível e em qualquer modalidade profissional, seja por carga horária de plantão, seja por distribuição de horário de plantão." (2) 
"o Ensino a Distância, no meu entendimento, a primeira coisa que traz é a flexibilidade para o profissional se atualizar, se capacitar, seja por educação continuada ou permanente, de uma maneira mais confortável à sua realidade. Esse é o primeiro ganho." (2)

"(Vejo) alguns aspectos positivos, por exemplo, a facilidade da pessoa continuar exercendo a sua atividade e nas horas livres ou dentro de uma programação que ela tenha de horário, de fazer os seus cursos.” (6)

"As pessoas têm necessidades que a obrigatoriedade, o horário obrigatório, londrino, europeu, não funciona para quem levanta às 5 h da manhã, entende? O aluno não produz como poderia produzir." (5)

"trata da questão de levar a educação para os pontos mais remotos do país, e também dos profissionais de saúde muitas vezes se recusarem a trabalhar dentro do território nacional ou mesmo do estado nos quais vivem por conta dessa impossibilidade de realizar cursos, de se aperfeiçoar." (5)

"eu acredito que se a gente abrisse uma planilha de negócios aqui, ainda é mais vantajoso investir nisso (EaD) e levar a educação via telecomunicação para outros locais." (5)

"o aluno em sala presencial quer ir embora, às vezes, porque ele tem diversos fatores sociais que contribuem pra isso (tem que pegar 3 ônibus, tem que chegar em casa e passar o uniforme do filho...)." (5)

"às vezes chega 10h da noite o cara já tá meio corpo fora numa universidade tradicional." (5)

"Ele já cuidou do filho, já fez suas atividades domésticas básicas ou voltou do trabalho..." (5)

"é gente que trabalha nos finais de semana também, que tem jornada pelo menos aos sábados, ou que trabalham 12×36, e que assim, não tem previsão de folga, então estuda no horário que pode." (5)

"às vezes se deve a todos esses fatores que ele tem condição de resolver dentro da casa dele antes de acessar a plataforma." (5)

"Primeiro eu acho importante pontuar que hoje em dia a gente tem que pensar em educação, muito mais focado pra disponibilidade que a pessoa tem, do que como uma premissa de crescimento." (5)

"Na fisioterapia isso é muito comum, as pessoas trabalham em seus empregos, passam em concurso, começam a trabalhar, aí depois correm atrás de uma especialização." (4) 
"tendo em vista a dificuldade das pessoas com os plantões e a dificuldade do presencial de reunir, agrupar profissionais em certos momentos." (3)

"eu acredito muito no EaD. Eu acho que ele veio para sanar a necessidade que a gente tem de ter disponibilidade, de poder se organizar dentro da nossa rotina para poder estudar." (3)

"cada vez mais eu vejo a dificuldade que as pessoas têm de aderir a cursos de pós-graduação, devido à sua rotina. Eu tô nesse caminho da pósgraduação pelo menos há uns doze anos e eu vejo que, às vezes, as pessoas começam e desistem... muitas são mulheres, tem filhos, tem plantão, o trabalho de 12x36, de final de semana... então é difícil encontrar um momento para oferecermos cursos presenciais com a adesão de muitas pessoas." (3)

"eu acho que o EaD vem pra isso, para garantir que as pessoas possam estudar dentro da rotina delas." (3)

"os alunos fazem o curso dentro da possibilidade que eles têm, nos horários que eles podem e de uma forma muito mais regrada." (5)

"As pessoas procuram crescer profissionalmente dentro dos seus horários, diante das suas particularidades." (5)

"A educação hoje precisa caber na vida da pessoa. Ela deixou de ser uma obrigação simples e passou a ser uma coisa que precisa caber na vida dela." (5)

Os plantões em horários dos mais diferentes, os casos em que os profissionais da saúde precisam trabalhar em dois empregos e suas vidas pessoais, podem impedir o acesso dessas pessoas aos cursos de especialização.

No entanto, outro ponto muito importante em que a EaD faz diferença e que devemos ressaltar é a dificuldade de acesso nos locais mais distantes. Essa é uma realidade que causa um ciclo vicioso na qualidade de saúde das populações mais afastadas dos grandes centros.

Visto que a capacitação é fundamental, notamos que os profissionais evitam ir para essas localidades, muitas vezes por perceberem que terão suas carreiras estagnadas se o fizerem, e os oriundos dessas regiões, ou saem para se especializarem, ou ficam e cuidam da população sem capacitação ou atualização. Mais uma vez, a população mais carente perdendo sempre. 
A EaD é uma saída interessante para esses casos, pois é muito mais fácil e barato abrir um polo e prover uma estrutura de acesso para os estudantes, do que abrir um campus e levar professores qualificados para essas locais.

"no Brasil, onde as boas informações são concentradas em São Paulo, profissionais de outras regiões mais distantes não dispõem de tantos cursos, bons cursos, ou não têm recursos para vir para São Paulo ou Rio para se especializar, o EAD vai até eles." (1)

"O principal é a facilidade do acesso ao local e o horário que pode fazer seu próprio ensino." (1)

"quando a gente pensa em estados como Pará, Amazonas, Rondônia, Acre, que são muito distantes, o EaD é um divisor de águas, é uma oportunidade que o EaD na área da saúde oferece para que o profissional possa se aperfeiçoar." (9)

"eu vejo o EaD como uma opção de estudo, de aprendizado, de aprimoramento profissional, principalmente para os colegas que estão mais distantes. Eu vejo de uma forma muito positiva." (9)

"O Brasil é um país enorme, é um país continental com uma grande diferença de formação entre Norte, Nordeste, Sul, Sudeste e Centro-Oeste." (8)

"se a gente for pensar na realidade aqui do Sul e Sudeste, pra gente é fácil ter acesso a bons profissionais, a boas instituições de formação, fazer um curso... mas quando a gente pensa num universo maior, no Norte, Nordeste e Centro-Oeste, não é fácil você ter profissional qualificado na região para ministrar os cursos, e também não encontra docentes que tenham a disponibilidade de se deslocar com uma frequência para ministrar esses cursos, pegar 4-5 horas de vôo... 6 horas! Perder um tempão se deslocando de um lugar para outro pra passar um sábado e um domingo." (8)

Isso também vemos em pequena escala, pois não é fácil para todos se deslocarem nas grandes cidades. Dependendo do horário, pode levar horas.

"eu vejo o ensino à distância como uma nova maneira, uma adaptação do mundo moderno para esse profissional ter cada vez mais capacitações, se especializar cada vez mais, mesmo com o tempo cada vez menor pra ir fisicamente, de se deslocar." (4)

Esses cursos têm a capacidade, inclusive de alcançar pessoas fora do Brasil, para estudantes e, principalmente países, que falam a língua portuguesa. 
"tenho alunos que são da África, de países que falam a língua portuguesa. É uma dificuldade para eles e a nossa instituição consegue chegar lá com os nossos cursos, e isso é excelente." (1)

Também precisamos considerar a diferença dos custos de um curso de especialização na modalidade presencial e na modalidade EaD. Com certeza, principalmente a longo prazo, os cursos em EaD custam menos, portanto as instituições podem praticar preços mais acessíveis com os estudantes.

"É uma tendência de mercado. O mercado exige que o profissional tenha qualificação, e os melhores cursos, principalmente na área da saúde, são os mais caros." (4)

Podemos assim, perceber o quanto a EaD pode melhorar o acesso aos cursos de especialização. Isso vai aumentar o número de pessoas mais capacitadas para tratar da saúde da população, trazendo mais acurácia e qualidade.

\section{O papel das Tecnologias de Informação e comunicação}

É fato que o avanço das Tecnologias de Informação e Comunicação foi o que alavancou a expansão dos cursos lato sensu na modalidade EaD. Elas trazem, além da otimização da interação dos indivíduos que não estão no mesmo ambiente, uma interface de simuladores que, cada vez mais, mimetizam muito bem as experiências reais, trazendo muitas possibilidades.

"hoje temos a oportunidade de oferecer tecnologia pro aluno. $O$ individuo pode colocar um óculos $3 \mathrm{D}$ e ver as estruturas saindo da tela, e isso o professor pode usar dentro do curso que ele leciona, ele tem liberdade pra isso, e isso ajuda a prender de verdade a atenção do aluno, de um jeito que ele aprenda o conteúdo e que isso tenha uma relação emocional e afetiva." (1)

"antes a gente falava muito de EaD e a ferramenta era o ambiente virtual, um portal, enfim... eu acho que hoje a gente tem muito mais ferramentas que propiciam que as pessoas aprendam." (3)

Ainda assim, as ferramentas que proporcionam a troca de informação, de experiências com pessoas com as mais diferentes realidades, e a possibilidade de 
discussões, são as mais amplamente utilizadas, até por conta da diferença de custos.

Porém, estas já têm uma posição muito importante para a disseminação do conhecimento,

"A gente tem uma série de informações que podem ser passadas de forma eletrônica. Para algumas disciplinas eu acho que não vai ter saída mesmo, a caminhada vai ser para os cursos EaD." (6)

"você posta algo, o cara tá lá em Roraima e discute com o cara que tá lá em Londrina. Tá todo mundo na mesma página criando discussões sobre a mesma coisa." (5)

"Eu acho que é uma tendência natural e eu sou favorável porque sou adepto da tecnologia." (6)

No entanto, os professores têm consciência que o uso da tecnologia de forma aleatória não é suficiente para alcançar um ensino de qualidade,

"ter vários tipos de tecnologia como chat, fórum... auxilia. Mas eu acho que elas apenas ajudam no processo ensino-aprendizagem." (7)

"eu trabalhei com algumas plataformas, alguns AVAs, e não é isso que faz a diferença. Não é você ter um melhor ambiente, com uma super tecnologia, com mil possibilidades de interação que vai garantir um bom curso." (8)

"não é uma tecnologia, não é um ambiente virtual de aprendizagem, mas sim uma série de combinações que você vai usar para facilitar esse acesso." (8)

"hoje eu acredito que a gente tenha muito mais ferramentas, e para elas há muitas metodologias que permitem que o aprendizado seja atual, que permita a discussão, o envolvimento de vários alunos, tanto entre eles, como com a tutoria..." (3)

O uso das TICs não são garantia de avanços tecnológicas, apenas proporcionam formas de recriar um ambiente que favoreça a aprendizagem significativa do estudante na EaD. ${ }^{63}$

Em suma, podemos dizer que os professores têm a ideia da importância que metodologias de ensino tem para o uso das tecnologias disponíveis nos cursos lato sensu em EaD no processo de ensino aprendizagem. 


\section{A importância das metodologias de ensino para os cursos lato sensu das áreas da saúde}

Como visto na categoria anterior os professores percebem que é preciso muito mais que a tecnologia para que o curso lato sensu na modalidade de EaD tenha qualidade e forme bons profissionais, ou seja, o modo como essas ferramentas são utilizadas é que vai fazer diferença no processo de ensino aprendizagem,

“(As metodologias de ensino) são importantíssimas! Não é só o material, a gente tem que saber como vai aplicar aquele material e como usaremos as ferramentas disponíveis." (7)

"As metodologias têm que estimular a busca, a curiosidade..." (4)

"A gente é muito visual, então uma metodologia ativa, que tenha outros recursos que envolvam áudio, vídeo, experiências, com indicação de outras leituras ou de outras fontes de mídia para a aprendizagem é fundamental." (4)

"a gente tem um dinamismo muito grande na área da saúde, o material e as discussões precisam ser muito atuais, então não dá pra se pautar nas ferramentas que a gente usava antigamente." (3)

"se as metodologias forem bem estruturadas e estiverem bem planejadas, só temos a ganhar, porque aí o curso tem, de fato, qualidade." (3)

"a metodologia é crucial, sem ela a gente não vai ter um curso dentro do paradigma correto, se você não tiver um desenho pedagógico, um método de trabalho compatível, ele vai estar fadado ao fracasso." (2)

"eu acredito que os cursos têm que ser muito bem estruturados para garantir várias oportunidades de aprendizagem para o aluno." (3)

Os professores também já sinalizam que perceberam que as metodologias de ensino são importantes e devem ser bem planejadas na construção de um curso/disciplina, seja ele em EaD ou presencial, que cada ação precisa ser planejada para que seja efetiva.

“Eu vejo as metodologias como ferramentas que são nosso braço direito em termos de ensino-aprendizagem. Não dá pra dissociar mais." (9) 
"(As metodologias de ensino) são uma perspectiva de informação que acompanham uma tendência tecnológica global, saindo daquela mesmice da sala de aula, expondo o individuo a uma experiência muito mais compatível com o que a gente vem vivendo hoje, com trabalho colaborativo, trabalho assíncrono e uso de ferramentas diversas." (2)

Também estão conseguindo perceber a importância do professor no desenvolvimento dessas metodologias com o intuito de alcançar os objetivos de aprendizagem. As falas trazem que a experiência do professor é ponto central nesse processo.

"Entra a ideia de cada professor, com o objetivo de facilitar para o estudante assimilar conteúdos extras dentro dessa metodologia, como novas tecnologias... isso que vai atrair o estudante, que vai prendê-lo e vai tornar a metodologia única." (1)

"Eu, em uma fala, em uma mediação, posso levar o aluno a pensar de forma reflexiva... de forma integrada." (8)

"Criar estratégias onde o aluno não está só assistindo a aula e sim, sendo ativo nesse processo." (8)

"Não dá pra você achar que só o que você postou no AVA seja a única forma de comunicação com o aluno. Na verdade, é uma combinação de ferramentas que você vai utilizar pra tentar fazer o vínculo com esse aluno." (8)

"não é simplesmente ensino presencial ou EaD, mas sim o tutor/professor ter a capacidade e a competência de mediar e levar a turma a um processo melhor de aprendizagem." (8)

"é o papel central do tutor/professor na capacidade de mediar o ensino a distância." (8)

O professor/tutor precisa se perceber como mediador e até instigador na busca pelo conhecimento, utilizando metodologias que o ajudem a direcionar os estudantes na construção do próprio conhecimento.

Também notamos a percepção de que as metodologias de ensino precisam estar em constante mudança, já que culturalmente estamos sempre mudando, estas precisam acompanhar as novas exigências que surgem.

Sobre essas exigências, Martín-Barbero ${ }^{64}$ questiona: 
"O que sabem nossas escolas, e inclusive nossas faculdades de educação, sobre as profundas modificações na percepção do espaço e tempo que vivem os adolescentes, inseridos em processos vertiginosos de desterritorialização da experiência e da identidade, e capturados numa contemporaneidade que confunde os tempo, debilita o passado e exalta o não-futuro fabricando um presente contínuo: feito por sua vez das descontinuidades de uma atualidade cada dia mais instantânea, e do fluxo incessante e embriagador de informações e imagens?"

É preciso então, conscientizar os professores, através da formação continuada sobre a importância da educação no mundo moderno e de como ele precisa incorporar as tendências atuais, e as possibilidades efetivas que as tecnologias podem fornecer para a formação dos profissionais em sua prática docente.

"a cada dez anos a gente tem uma nova geração que entra no mercado educacional, com a visão e as necessidades de aprendizado totalmente diferentes daquela que terminou." (9)

"Eu acredito que com a própria questão da tecnologia, a própria questão dos meios de comunicação utilizados nos cursos EaD, essas (as metodologias de ensino) terão que ser revistas em algum momento pra facilitar a atuação do docente e também a absorção do conteúdo pelos alunos." (6)

O planejamento de um método para a utilização das ferramentas de ensino utilizadas nos cursos de EaD tem a capacidade de transformar a distância física na proximidade dos atores envolvidos nos cursos lato sensu nas áreas da saúde, proporcionando troca de experiências riquíssimas e muito importantes na evolução da aprendizagem dos estudantes.

Vygotsky, na sua teoria sócio-interacionista, pontua que o ambiente social e histórico estabelecido, na qual a teia de relações sociais é o ponto central do processo de aprendizagem. É no momento vivido que o conhecimento se constrói, apoiado na participação e colaboração do outro, ou seja, no social, tendo como meios de intercâmbio e estímulo à aquisição e busca desse conhecimento, a discussão em grupo e o poder de argumentação, como corroboram os professores nas falas a seguir: ${ }^{47}$ 
"Outro facilitador é a discussão em fóruns que existe normalmente nos cursos de pós-graduação EaD. Isso enriquece muito porque você conhece e discute com uma gama muito diversa de profissionais." (6)

"Eu tive a experiência, por exemplo, de um curso EaD que eu fiz de gestão, onde tinha desde administrador de empresas até médicos altamente especializados discutindo as contas de saúde. Isso foi bem enriquecedor porque nessas discussões a gente acabou aprendendo e ensinando ferramentas da área de gestão que tem aplicabilidade prática no dia-a-dia das pessoas." (6)

Apesar dessas colocações, alguns professores sentem que, em certos cursos, não é dada a devida importância para as metodologias de ensino. Eles percebem que em alguns casos há apenas uma troca de "local" de ensino, mas as abordagens continuam iguais. ${ }^{65}$

"a minha impressão é que a gente tem uma substituição dos cursos presenciais pelos cursos virtuais, mas nas metodologias didáticopedagógica não consigo ver uma mudança voltada para o ensino à distância, mas sim uma mimetização do ensino presencial mediado por computador." (2)

"Acredito que algumas coisas básicas da metodologia não serão mudadas, mas devido a essa gama de tecnologia que está envolvida nos cursos EaD, com certeza vai ter que ser feita uma revisão da parte metodológica, até pra gente conseguir ensinar de forma segura, com evidências científicas $e$ com credibilidade todas as informações necessárias." (6)

"Nos cursos EaD, tanto na faculdade (...) quanto na (...), a plataforma construída é a mesma. Você tem o método de ensino, o conteúdo que você tem que dar. Só que, ao invés de falar para 30 pessoas, você fala para uma câmera. Então eu não sei se existe uma metodologia própria para um curso EaD." (5)

Essa preocupação se mostra mais evidente quando falamos sobre cursos de especialização lato sensu nas áreas da saúde que envolvem conhecimentos técnicos além do teórico, pois estes percebem que esta etapa do aprendizado é importante e não pode ser preterida.

"mesmo num curso totalmente à distância, precisa ter a prática em algum momento, por meio de alguma parceria com outra instituição que possa desenvolver algumas atividades práticas para esse indivíduo aprender de forma completa." (4) 
"Tem vários estudos que mostram que nós aprendemos quando colocamos a mão na massa, explicamos, praticamos... então o EaD pode pecar nesses aspectos se for totalmente à distância..." (4)

"A única ressalva que eu faço é para alguns cursos de pós-graduação que requerem a destreza manual do profissional." (6)

"Quando você está no presencial você tem experiências que você não tem no EaD. Em termos de conteúdo ele cumpre o seu papel, só que eu acredito que a especialização também precisa trazer ao enfermeiro a expertise que ele precisa na prática." (7)

"eu acho que na parte prática o sistema EaD lato sensu é falho quando não oferece isso." (7)

"Se discute muito nos cursos da saúde a questão da prática. Como você vai ter a prática nos cursos EaD?" (5)

Essa última pergunta é um ponto chave muito discutido quando estamos falando de EaD nos cursos lato sensu nas áreas da saúde. Porém, em algumas falas percebemos que há a perspectiva de que a prática não precisa, necessariamente, estar dissociada da EaD.

"Muitas vezes eu já escutei esse discurso de que no EaD você não tem a prática que você precisa e isso pra mim é uma bobagem." (5)

"A prática o aluno vai adquirir no estágio tal qual no ensino presencial. $A$ gente tá discutindo dinâmica de ensino, a gente não tá discutindo aula prática, a prática não tem que ser modificada." (5)

"o toque e a vivência são necessários, mas isso seria coberto com um laboratório...” (5)

"dependendo da possibilidade do aluno, ele conseguiria ter aulas práticas básicas e, posteriormente faria um estágio, porque o estágio ainda é obrigatório, mesmo no EaD." (5)

"Por mais que você faça um curso em saúde ou uma faculdade de direito, você precisa estagiar. Você faz um curso de economia, você precisa estagiar numa instituição financeira, fisicamente, em algum momento do curso, você vai ter que ter a disponibilidade para a prática, então eu não vejo isso como um impeditivo." (5)

"A prática é obrigatória, você tem que fazer o estágio, você precisa sair do seu quarto, da sua estação de trabalho e ir para a prática, assim como você tem que sair da sala de aula." (5) 
Percebemos nessas falas que a EaD não precisa ser excluída nos casos de cursos que requerem formação técnica, afinal, pode-se fazer parcerias como são feitas para o estabelecimento dos polos para atividades de laboratório. Já o estágio não tem que deixar de existir nesses cursos, poderá e deverá ser concluído como em um curso presencial.

Outro ponto importante no que concerne às metodologias de ensino nos cursos lato sensu na modalidade EaD é que não só traz a liberdade de horário e local para fazer as disciplinas, mas também a autonomia e disciplina são os pontos principais para os estudantes que ingressam nessa modalidade de curso. $O$ uso de metodologias que exercitem a busca ativa do conhecimento e a participação dos estudantes são muito apropriadas, principalmente nessa nova era digital, onde estamos acostumados a ter nossas questões respondidas em alguns cliques, seja perguntando para alguém mais experiente por mensagens ou ligações de áudio ou vídeo; seja procurando nas plataformas de busca ou assistindo a tutoriais, tudo pela internet.

"O ensino à distância exercita mecanismos do intelecto do individuo que não acontece no ensino presencial, desde a autonomia de estudo, os recursos textuais ou literários, que são muito maiores no virtual do que no presencial." (2)

"eles precisam ter disciplina, encontrar esse tempo dentro da rotina, que pode não ser imposto pelas instituições, pelos cursos, mas é um momento escolhido pelo próprio aluno, para ele conseguir, de fato, estudar e se especializar." (3)

"a ferramenta, a tecnologia, provoca o aluno para que ele busque conhecimento. Eu acredito que o aprendizado acontece muito por isso, ele não é um modelo pronto." (3)

"Eu acho que as ferramentas utilizadas no EaD provocam as pessoas para que elas busquem conhecer aquilo que as incomodam. Os fóruns, as discussões, as salas de aula virtuais, as dúvidas geradas por outras pessoas na plataforma... eu acho que esse é o melhor modelo para aprender." (3)

"algumas ferramentas e algumas metodologias são provocativas, trazem incômodos mesmo, e fazem com que as pessoas queiram buscar conhecimento, que queiram resolver problemas e buscar soluções..." (3) 
"É muito importante a capacidade do indivíduo de ter disciplina, porque, por mais que ele não vá fisicamente a um lugar, ele precisa ter naquele momento." (4)

"essa pessoa precisa ter conhecer o que vai aprender pois, se tiver dúvidas, vai ter que procurar por si só." (4)

"essa falta de contato entre uma pessoa que tem um conhecimento maior com o aluno facilita. Então no EaD, esse indivíduo precisa ter iniciativa de buscar o próprio conhecimento." (4)

"Exige do aluno uma disciplina muito grande!" (4)

"faz com que o aluno se dedique e seja mais disciplinado." (5)

"quando ele entrava para fazer o módulo, estava realmente dedicado àquilo." (5)

"Essa forma de enxergar a educação por meio do EaD só fomenta o crescimento do aluno. A força motriz é a disponibilidade dele." (5)

"o EaD se encaixaria como uma forma de melhorar o seu horário, de contribuir com o seu horário e fazer com que o aluno se dedique mais, a força motriz de dedicação é do aluno. Então o curso flui melhor, o aluno se dedica mais." (5)

Essa atitude é a garantia para o sucesso da aprendizagem na EaD em saúde. O estudante conquista a autonomia para decidir sobre seus horários de estudo, iniciativa para pesquisar e assume a responsabilidade da sua própria educação. ${ }^{66}$

Toda essa dedicação, disciplina e autonomia também faz com que este estudante exija a mesma postura dos professores, tutores e instituições. Com o passar do tempo, os cursos que não corresponderem à essas expectativas estarão fadadas ao fracasso, pois os estudantes não permanecerão em um curso/instituição que não corresponda às suas expectativas,

"Eu acho que o aluno que se propõe a fazer esse tipo de estudo, de proposta de aprendizado, é um aluno mais maduro, que sabe o que quer. Ele busca, participa mais. Eu sinto isso. Eles cobram mais da gente, querem ser respondidos, querem que tiremos as dúvidas... eu os acho bem mais participativos do que os alunos de sala de aula. Eu tenho observado isso porque também leciono em curso presencial." (9)

"o que eu observo é que se o aluno não está gostando, se não conseguiu se adaptar àquele ambiente, ele abandona o curso." (9) 
"eles buscam que o curso atenda às expectativas dele, e isso, pra mim, é o maior desafio das instituições que ofertam essa modalidade de aprendizado." (9)

Com isso, podemos perceber que tanto a forma de ensinar está em constante evolução, evolução esta que acompanha as mudanças culturais da nossa sociedade, mas que a forma de ensinar, ou seja, o processo de ensino aprendizagem, é dependente das metodologias de ensino para nortear seu caminho, e que estas devem estar em constante adaptação para caber na realidade dos estudantes que procuram e procurarão se especializar em sua profissão. 

Conclusão 


\section{CONCLUSÃO}

Os resultados da pesquisa se encontram em consonância com os objetivos da tese. Os dados nos mostram quais e como as ferramentas disponíveis nos dias de hoje são utilizadas, e quais os objetivos dessas escolhas no desenvolvimento dos cursos de especialização lato sensu nas áreas das ciências da saúde.

Além disso, as falas trazidas pelas entrevistas evidenciam as impressões dos professores/coordenadores desses cursos, suas expectativas e preocupações no que se refere a qualidade e aplicabilidade dessa modalidade de ensino nos temas referentes às disciplinas na formação dos profissionais da saúde.

As categorias que emergiram dessas falas, mostraram que os discursos dos entrevistados estavam em concordância no que diz respeito a sua essência, o que evidencia um consenso nas impressões que a EaD vem causando nos docentes.

A EaD está trazendo uma nova perspectiva para a expansão e aprofundamento do conhecimento, bem como para a formação profissional de nível superior. Suas ferramentas possibilitam que a "distância" seja virtualmente diminuída, já que abre diversos meios para promover a comunicação e troca de experiências entre os atores do processo de ensino aprendizagem.

Diante disso, estamos assistindo a expansão progressiva de oferta de cursos de especialização lato sensu nessa modalidade. Isso vem promovendo um alcance desses cursos por uma maior quantidade de profissionais que buscam se especializar, mas não o conseguiriam em cursos presenciais com horário pré-estabelecido.

Essa realidade faz com que, apesar de certa resistência e, pode-se dizer, preconceito, por parte dos profissionais das áreas das ciências da saúde, essa modalidade de ensino tem englobado cada vez mais cursos de especialização e formação nesses temas, pois esses são necessários para a disseminação da oportunidade de qualificação dos profissionais da saúde brasileiros.

Esse preconceito é, de certa forma, justificável, devido ao caráter que é atribuído aos profissionais de saúde, pois essas profissões ligadas ao cuidado, preconizam um contato quase íntimo entre os trabalhadores e seus clientes, portanto, 
aceitar que é possível aprender a cuidar sem contato físico com os professores e colegas, parece inadequado.

Essa impressão é muito forte e presente nas falas, porem pudemos perceber no discursos uma abertura, já que os professores estão vivendo e percebendo a interação e trocas que são possíveis com o uso adequado das ferramentas disponibilizadas nas plataformas e ambientes utilizados na EaD.

Para que a EaD tenha sucesso, suas ferramentas precisam ser escolhidas com propriedade e intenção, definindo como serão trabalhadas em prol da construção de cursos com foco na qualidade e segurança para profissionais e pacientes.

Essa é uma preocupação muito levantada e traz à tona discussões a respeito da necessidade de atualização e adequação das metodologias de ensino aplicadas no desenvolvimento dos cursos de especialização na EaD. Por outro lado, houve uma clareza de que os cursos presenciais também precisam de uma reciclagem no que se refere ao uso de metodologias de ensino apropriadas.

Essa pesquisa mostrou que os professores estão cientes da presença, inevitabilidade, funcionalidade e oportunidades que esse tipo de curso pode proporcionar. Ao mesmo tempo, levantam a necessidade do uso adequado dessas novas ferramentas, para que não haja prejuízo para a formação dos profissionais da saúde e da população por eles atendida.

O acesso à qualificação que a $\mathrm{EaD}$ proporciona precisa ser usado com responsabilidade e sabedoria, para que os objetivos buscados pelos estudantes e profissionais sejam alcançados, o que vai garantir que os conhecimento seja adquirido com qualidade e profundidade, aumentando ainda mais a possibilidade de acesso aos profissionais a essa modalidade de ensino, visando a melhoria da assistência de saúde para a população.

Por fim, podemos afirmar que as metodologias de ensino são muito importantes e devem ser planejadas durante a construção e desenvolvimento de cursos a distância. Essa premissa vai propiciar que suas potencialidades sejam estrategicamente utilizadas. 


\section{Considerações Finais}


Essa pesquisa nos trouxe a importância de se pensar metodologicamente os cursos de especialização oferecidos para os profissionais de saúde, com ênfase no uso de metodologias adequadas ao uso das ferramentas disponibilizadas nas plataformas de EaD.

Percebemos que culturalmente, essa modalidade de ensino estará cada vez mais presente em nossas vidas, pois visto que a forma de busca de conhecimento está mudando, os professores e idealizadores dos cursos precisam estar cientes das necessidades desse novo profissional e de seus pacientes.

Precisamos trazer para esses cursos a preocupação de Vygotsky em entender o funcionamento psicológico do ser humano, integrando aspectos biológicos e culturais, integrando esses ao processo de ensino aprendizagem ancorados na teoria de Vygotsky, pois esta enfatiza o papel da aprendizagem e do desenvolvimento humano, valorizando a intervenção pedagógica consciente. ${ }^{44}$ 



\section{Referências}




\section{REFERÊNCIAS}

1. MoodleDocs. Moodle. [Online].; 2006 [cited 2019 agosto 21. Available from: https://docs.moodle.org/all/pt_br/História_do_Moodle.

2. Holanda VR, Pinheiro AKB, Holanda ER, Santos MCL. Ensino e Aprendizagem em Ambiente Virtual: Atitude de Acadêmicos de Enfermagem. REME. 2015 jan/mar; 19(1): 141-147.

3. Holanda VR, Pinheiro AKB, Pagliuca LMF. Aprendizagem na educação online: análise de conceito. Rev Bras Enferm. 2013; 66(3):406-11.

4. Holanda VR. Hipermídia educacional para o ensino das doenças sexualmente transmissíveis: construção, validação e avaliação [tese]. Fortaleza (CE): Universidade Federal do Ceará. Programa de Pós-Graduação em Enfermagem; 2014.

5. França CL, Matta KW, Alves ED. Psicologia e Educação a Distância: Uma Revisão Bibliográfica. Psicologia: ciência e profissão. 2012; 32(1): 4-15.

6. Abbad GD, Zerbini T, Souza DB. Panorama das pesquisas em educação a distância no Brasil. Estudos de Psicologia. 2010, set-dez; 15(3): 291-298.

7. Pesce L. Educação a Distância e formação de educadores: a contribuição dos desenhos didáticos dialógicos. 31a Reunião Anual Da Anped. Disponível em <http://www.anped.org.br/reunioes/30ra/index.html>. Acessado em 8/10/2014.

8. Gonçalves MBB, Rabeh SAN, Terçariol CAS. Contribuição da educação a distância para o conhecimento de docentes de enfermagem sobre avaliação de feridas crônicas. Rev. Latino-Am. Enfermagem. 2015; 23(1):122-9.

9. Alonso KM. A expansão do ensino superior no Brasil e a EaD: Dinâmicas e lugares. Educ. Soc. [online]. 2010, 31(113): 1319-1335.

10. Barilli EC, Ebecken NF, Cunha GG. A tecnologia de realidade virtual como recurso para formação em saúde pública à distância: uma aplicação para a aprendizagem dos procedimentos antropométricos. Ciência \& Saúde Coletiva. 2011; 16:1247-1256.

11. Amarilla Filho P. Educação a distância: uma abordagem metodológica e didática a partir dos ambientes virtuais. Educação em Revista. 2011, Ago; 27(2):41-72.

12. Camacho AC. Análise das publicações nacionais sobre educação à distância na enfermagem. Revista Brasileira de Enfermagem. 2009, jul-ago; 62 (4):588-593.

13. Candido MCFS, Furegato ARF. Transtornos depressivos: um material didático para educação à distância. Esc Anna Nery Rev Enferm 2008. 12 (2)(3): 473-8.

14. Rodrigues RCV, Peres HHC. Panorama brasileiro do ensino de Enfermagem On-line. Rev Esc Enferm USP. 2008; 42(2): 298-304. 
15. Parker EB, Wassef ME. Flexible online learning options for graduate nursing students. Nurse Educ. 2010; 35: 243-247.

16. Marfra L, Tura M. (3) In: Silva M. Educar em nosso tempo: desafio da teoria social pós-moderna. Rio de Janeiro: Quartet; 2005.

17. Rangel M. Métodos de ensino para a aprendizagem e a dinamização das aulas. $3^{a}$ ed. Campinas: Papirus; 2007.

18. Paim AS, lappe NT, Rocha DLB. Metodologias de ensino utilizadas por docentes do curso de enfermagem: enfoque na metodologia problematizadora. Enfermería Global. 2015; (37): 153-9.

19. Vilarinho LRG. Didática: Temas Selecionados. Rio de Janeiro: Livros Técnicos e Científicos; 1985.

20. Evangelista YSP, Chaves EV. Ensino de química: uma realidade concreta do saber. In: 3o Econtro Nacional de Ensino de Ciências da Saúde e do Meio Ambiente; 2012 Maio [Internet]. Niterói (RJ), Brasil. Niterói: Universidade Federal Fluminense (UFF); 2012.

21. Kuethe JL. O processo ensino-aprendizagem. $3^{a}$ ed. Porto Alegre: Globo; 1978.

22. Harb JN, Terry RE, Hurt PK, Williamson KJ. Teaching through the cycle: application of learning style theory to enginnering education at Brigham Young University. 2a ed. Provo/UT: Brigham Young University Press; 1995.

23. Inoue CS, Santos RLS, Santos APS dos, Souza GHS de, Lima NC. A educação na atualidade: uma análise pautada na subjetividade das metodologias de ensino e nas Tecnologias de Informação e Comunicação (TIC). Multifaces. 2018; 1(2): 1-19.

24. Moore MG, Kearsley G. Educação a distância: uma visão integrada - Edição especial ABED - Associação Brasileira de Educação a Distância. São Paulo: Thomson Learning, 2007.

25. Barbosa BP. Educação a Distância: a articulação das Tecnologias Digitais de Informação e Comunicação (TDIC) e os estruturantes didáticos (2002-2012) [dissertação]. São Paulo (SP): Universidade de São Paulo. Programa de PósGraduação em Educação; 2015. 263p.

26. Malheiros APS. Educação matemática on-line: a elaboração de projetos de modelagem [dissertação]. Rio Claro (SP): UNESP; 2008. 187 p.

27. Pretti O. Educação a Distância: uma prática educativa mediadora e mediatizada. In: Pretti O. Educação a distância: inícios e indícios de um percurso. Cuiabá: NEAD/IEUFMT, p. 15-56, 1996.

28. Brasil. Lei n 9.394/1996. Estabelece as Diretrizes e Bases da Educação Nacional. Diário Oficial da União. 1996. 
29. Brasil. Lei $n^{\circ} 9.610 / 1998$. Altera, atualiza e consolida a legislação sobre direitos autorais e dá outras providências. Diário Oficial da União. 1998.

30. Brasil. Lei n 13.005/2014. Aprova o Plano Nacional de Educação - PNE e dá outras providências. Diário Oficial da União. 2014.

31. Brasil. Lei $n^{0} 13.620 / 2018$. Institui o dia 27 de novembro como o Dia Nacional de Educação a Distância. Diário Oficial da União. 2018.

32. Brasil. Decreto $n^{\circ} 8.752 / 2016$. Dispõe sobre a Política Nacional de Formação dos Profissionais da Educação Básica. Diário Oficial da União. 2016.

33. Brasil. Decreto $n^{\circ} 9.057 / 2017$. Regulamenta o art. 80 da Lei $n^{\circ}$ 9.394. Diário Oficial da União. 2017.

34. Brasil. Decreto $n^{\circ}$ 9.235/2017. Dispõe sobre o exercício das funções de regulação, supervisão e avaliação das instituições de educação superior (IES) e dos cursos superiores de graduação e de pós-graduação lato sensu, nas modalidades presencial e a distância, no sistema federal de ensino. Diário Oficial da União. 2017.

35. Brasil. Resolução $n^{\circ} 3 / 2012-C N E / C P$. Altera a redação do artigo que estabelece Diretrizes Operacionais para a implantação do Programa Emergencial de Segunda Licenciatura para Professores em exercício na Educação Básica Pública a ser coordenada pelo MEC, inserindo a educação a distância. Diário Oficial da União. 2012.

36. Brasil. Resolução n 1/2016-CNE/CES. Estabelece Diretrizes e Normas nacionais para a oferta de programas e cursos de educação superior na modalidade a distância. Diário Oficial da União. 2016.

37. Brasil. Resolução $n^{0} 1 / 2018-C N E / C E S$. Estabelece diretrizes e normas para a oferta dos cursos de pós-graduação lato sensu denominados cursos de especialização, no âmbito do Sistema Federal de Educação Superior, e dá outras providências. Diário Oficial da União. 2018.

38. Brasil. Portaria Normativa $n^{\circ}$ 2/2007-MEC - Dispõe sobre procedimentos de regulação e avaliação da educação superior na modalidade a distância. Diário Oficial da União. 2007.

39. Brasil. Portaria n 90/2019-CAPES. Dispõe sobre os programas de pós-graduação stricto sensu na modalidade de educação a distância. Diário Oficial da União. 2019.

40. Muller M. MEC muda regras para cursos de pós-graduação lato sensu [site]. São Paulo: ICTQ [acesso em 12 de ago de 2019]. Disponível em: https://www.ictq.com.br/guia-de-carreiras/749-mec-muda-regras-para-cursos-de-posgraduacao-lato-sensu

41. Brasil. Lato sensu - saiba mais [site]. Brasília: Portal MEC [acesso 12 de ago de 2019]. Disponível em: http://portal.mec.gov.br/component/tags/tag/32116. 
42. Oliveira MK. Vygotsky: Aprendizado e Desenvolvimento: um processo sóciohistórico. São Paulo: Scipione; 2009.

43. Oliveira MK. Vygotsky e o processo de formação de conceitos. In: La Taille Y, Oliveira MK, Dantas H. Teorias psicogenéticas em discussão. São Paulo: Summus; 1992.

44. Carlin DS. Relação interpessoal professor aluno no ensino profissional técnico em enfermagem: repercussões na aprendizagem atitudinal [dissertação]. São Paulo (SP): Universidade de São Paulo. Programa de Pós- Graduação em Gerenciamento em Enfermagem; 2011. 105p.

45. Oliveira ESG, Nogueira MLL. Educação a distância e formação continuada de professores: Novas Perspectivas. Rev Colabora. 2005; 3(10).

46. Vygotsky L. A formação social da mente. São Paulo: Martins Fontes; 2003.

47. Heimann C. Capacitação pedagógica de docentes de enfermagem: desenvolvimento e avaliação de um curso a distância [dissertação]. São Paulo (SP): Universidade de São Paulo. Programa de Pós-Graduação em Gerenciamento em enfermagem; 2012. 157p.

48. Chizzotti A. Pesquisa qualitativa em ciências humanas e sociais. $4^{a}$ ed. São Paulo: Editora Vozes, 2011. 144 p.

49. Minayo MCS. O desafio do conhecimento: pesquisa qualitativa em saúde. $14^{a}$ ed. São Paulo: Hucitec; 2012. 408p.

50. Leopardi MT, Marziale MP. Educação a distância: indo além. Rev. Latino-am. Enfermagem. 2007 (nov-dez); 15(6):1059-1060.

51. Faugier J, Sargeant M. Sampling hard to reach populations. Journal of Advanced Nursing. 1997; 26:790-797. (3)

52. Dewes JO. Amostragem em Bola de Neve e Respondent-Driven Sampling: uma descrição dos métodos [monografia]. Porto Alegre (RS): Universidade Federal do Rio Grande do Sul. Departamento de Estatística; 2013. 51p. (4)

53. Silva LRC, Damaceno AD, Martins MCR, Sobral KM, Farias IMS. Pesquisa documental: alternativa investigativa na formação docente. XI Congresso Nacional de Educação - EDUCERE; III Encontro Sul Brasileiro de Psicopedagogia. PUCPR, 2009.

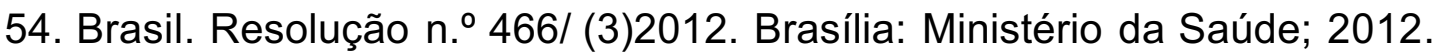

55. Blog Unileya [site]. Fórum em EAD: como participar de maneira eficiente. [acesso em 27 ago 2019]. Disponível em: https://blog.unyleya.edu.br/dicas-deestudo/forum-em-ead-como-participar-de-maneira-eficiente/ 
56. Significados [site]. Significado de blog. 2017 [acesso em 27 ago 2019]. Disponível em: https://www.significados.com.br/blog/

57. Marchiori PZ. "Ciberteca" ou biblioteca virtual: uma perspectiva de gerenciamento de recursos de informação. Ci. Inf. 1997; 26(2).

58. Infoescola [site]. Realidade virtual. [acesso em 27 ago 2019]. Disponível em: https://www.infoescola.com/tecnologia/realidade-virtual/

59. Que conceito [site]. Realidade aumentada. [acesso em 27 ago 2019]. Disponível em: https://queconceito.com.br/realidade-aumentada

60. Portal educação [site]. Ambiente virtual de aprendizagem. [acesso em 27 ago 2019]. Disponível em:

https://www.portaleducacao.com.br/conteudo/artigos/educacao/ambiente-virtual-deaprendizagem/16512

61. Revista Veja [site]. Wiki é um sucesso, mas o que é Wiki? [acesso em 27 ago 2019]. Disponível em:

https://veja.abril.com.br/blog/sobre-palavras/wiki-e-um-sucesso-mas-o-que-e-wiki/

62. Oliveira M. Educação a Distância como Estratégia para Educação Permanente em Saúde: possibilidades e desafios. Rev.bras.enferm. 2007 (set-out); 60(5).

63. Antunes MCS, Gomes HR, Gomes EPF, Antunes NS. Educação dos profissionais da saúde através da EaD: um olhar no Rio Grande do Norte. Rev. Bras. da Educ. Profissional Tecnológica. 2013; 6(1): 9-18.

64. Martín-Barbero J. Ofício de cartógrafo: Travessias latino-americanas da comunicação na cultura. São Paulo: Edições Loyola, 2004.

65. Lostada LR, Cruz DM. A EaD como um horizonte de novas possibilidades didático-pedagógicas. Unisul. 2017 (jan-jun); 11(19): 188-208.

66. UNIVERSIDADE FEDERAL DO CEARÁ. Faculdade de Medicina. Núcleo de Tecnologias e Educação a Distância em Saúde. Curso de especialização em saúde da família: planejamento e avaliação das ações. Fortaleza, 2010. 


\section{Obras consultadas}


Abbad GS, Carvalho RS, Zerbini T. Evasão em curso via internet: explorando variáveis explicativas. Revista de Administração de Empresas Eletrônica. 2005; $5(2)$.

Almeida EB. Educação a distância na Internet: abordagens e contribuições dos ambientes digitais de aprendizagem. Educação e Pesquisa, São Paulo. 2003 (jul); 29(2):327-340.

Azer N, Xhi X, Gara C, Karmali S, Birch WD. "iBIM" - Internet - based interactive modules: an easy and interesting learning tool for general surgery residents. Can $\mathrm{J}$ Surg. 2014 (abr); 52(2):E31-E35.

Bravo RS. Técnicas de investigação social: Teoria e exercicios. 7 ed. Ver. Madrid: Paraninfo, 1991.

Calado SS, Ferreira SCR. Análise de documentos: método de recolha e análise de dados. Disponível em:

http://www.educ.fc.ul.pt/docentes/ichagas/mi1/analisedocumentos.pdf

Campos GWS. Saúde Paidéia. São Paulo: Hucitec, 2007.

Fidelis PCB. Características individuais: Preditores de Aprendizagem no Ensino Superior a distância [dissertação]. Ribeirão Preto (SP): Universidade de São Paulo. Departamento de Psicologia, Faculdade de Filosofia, Ciências e Letras de Ribeirão Preto; 2018. 117p

Formiga M. A terminologia da EAD. In: Litto F, Formiga M (orgs.). Educação a Distância: o estado da arte. São Paulo: Persons. 2009; 422-434.

Franco SK (Org.). Informática na educação: estudos interdisciplinares. Porto Alegre: Editora da UFRGS. 2004.

Kulier R, Corpus SF, Zamora J, Hadley J, Malick S, Das K, et al. The effectiveness of a clinically integrated e-learning course in evidence-based medicine: A cluster randomised controlled trial. BioMed Central Ltd. 2009. Acesso em 03 de Out de 2014, disponível em: www.biomedcentral.com/1472-6920/9/21

Lévy P. Cibercultura. Rio de Janeiro: 34, 1999; 193.

Martins TY, Ribeiro R, Prado C. (jul-ago de 2011). Transdisciplinaridade na educação à distância: um novo paradigma no ensino de enfermagem. Rev. Bras. Enferm. 2011 (jul); 64(4):779-782.

Mendes JAC, Marziale MHP. As novas exigências da comunicação científica na era do conhecimento. Revista Latino Americana de Enfermagem 2002, (mai); 10(3).

Moran JM. Os modelos educacionais na aprendizagem on-line. Disponível em: http://www.eca.usp.br/prof/moran/modelos.htm>. Acessado em 18/10/2014. 
Mutti RM, Varini MAXT. Para uma posição enunciativa no discurso pedagógico mediado por ambientes virtuais de aprendizagem. Interface. 2008; 12(25):347-361.

Nunes TWN, Franco SRK, Silva VD. Como a educação a distância pode contribuir para uma prática integral em saúde? Rev Bras Educ Med. 2010; 34(4):554-64.

Paulon SM, Carneiro MF. A Educação a distância como dispositivo de fomento às redes de cuidado em saúde. Interface. 2009; 13:747-757.

Perry W, Rumble GA. Short guide to distance education. Cambrigde: International Extension College, 1987.

Prado C (org.). Práticas pedagógicas em enfermagem: processo de reconstrução permanente. São Paulo: Difusão Editora, 2013.

Prado C, Peres HHC, Leite MMJ. Tecnologia da informação e da comunicação em enfermagem. São Paulo: Atheneu, 2011.

Rodrigues RCV, Peres HHC. Desenvolvimento de ambiente virtual de aprendizagem em enfermagem sobre ressuscitação cardiorrespiratória em neonatologia. Rev Esc Enferm USP. 2013; 47(1):235-41.

Romiszowisky AJ. Aspectos da Pesquisa em EAD: In Litto F, Formiga M (orgs.). EducaCNao a Distlancia: o estado da arte. São Paulo: Persons, 2009; 422-434. 
Apêndices 


\section{Apêndice 1}

\section{TERMO DE CONSENTIMENTO LIVRE E ESCLARECIDO}

Convido o(a) Sr(a) para participar da pesquisa intitulada "Metodologia de ensino na educação aa distância em ciências da saúde: formação lato sensu", desenvolvida pela Sra. Daniele Soares Carlin.

O objetivo dessa pesquisa é analisar as metodologias de ensino na metodologia educação aa distância, em cursos lato sensu, nas áreas da saúde. Acredita-se que estudos com o intuito de desenvolver e aprimorar novos métodos de ensino, aprendizagem e de avaliação dos estudantes de cursos lato sensu, que envolvem ensino à distância são muito importantes para a qualidade da formação dos profissionais da saúde no Brasil.

Sua participação é voluntária e acontecerá por meio de preenchimento de um formulário de coleta de dados e uma entrevista que será gravada em áudio, para posterior transcrição do depoimento. A duração estimada da entrevista é de 30 minutos e ocorrerá em local designado por você, podendo ser por vídeo-chamada.

Durante a entrevista, você poderá sentir algum desconforto, pois o assunto tratado pode mobilizar sentimentos desagradáveis. Caso isso ocorra, haverá a suspensão da entrevista.

Você tem liberdade para retirar seu consentimento, sem qualquer prejuízo e a qualquer momento da investigação.

As informações obtidas serão analisadas em conjunto, não sendo divulgada a identificação de nenhum participante da pesquisa, garantindo, assim, o seu anonimato e a privacidade da sua participação.

Não há benefício direto ou previsão de custo com sua participação neste estudo. No entanto, caso você tenha algum gasto com transporte ou alimentação, decorrentes da pesquisa, haverá ressarcimento financeiro do mesmo.

Você poderá solicitar indenização em virtude de eventuais danos decorrentes da pesquisa.

Em qualquer etapa do estudo, você terá acesso ao pesquisador responsável pela investigação para esclarecimento de dúvidas.

A pesquisadora responsável por esse estudo é a Prof. Daniele Sores Carlin que pode ser encontrada no Departamento ENO da Escola de Enfermagem da Usp, situada na Av. Dr. Enéas de Carvalho Aguiar, 419, CEP 05403-000 - Cerqueira Cesar - São Paulo/SP - telefone (11) 991114738 e-mail - daniele.carlin@usp.br .

Este documento deverá ser rubricado em todas as suas páginas e assinado em suas duas vias.

Você receberá uma cópia desse documento rubricada e assinada pela pesquisadora.

Caso você tenha alguma consideração ou dúvida sobre a ética da pesquisa, entre em contato com o Comitê de Ética em Pesquisa (CEP) - Endereço - Av. Dr. Enéas de Carvalho Aguiar, 419 - Cerqueira César São Paulo/SP CEP - 05403-000 Telefone - (11) 3061-8858 e-mail - cepee@usp.br

Esta pesquisa atende todas as especificações da Resolução 466, de 12 de dezembro de 2012 que aprova as diretrizes e normas regulamentadoras de pesquisas envolvendo seres humanos. 
Assinatura

Assinatura do participante

Data:_________ 


\section{Apêndice 2}

\section{UNIVERSIDADE DE SÃO PAULO}

ESCOLA DE ENFERMAGEM

Pesquıss: Metodologia de Ensino na Educaçāo a Distância em Ciências da Saúde: Formaçāo Lato Sensu

Pesquisudoru: Daniele Soares Carlin

Orientadora: Maria de Fatima Prado Fernandes

ORIENTAÇ̃o DE PREENCHIMENTO:

- Assinalar as ferramentas utilizadas no(s) curso(s) Lato Sensu na modalidade de Educaçāo à Distância da instituiçẫo de ensino que você atua, pelo(s) qual(is) vocể responde esse formulário.

- Para as ferramentas assinaladas, descreva quais metodologias de ensino (ME) são empregadas na utiliza ção dessas ferramentas e seus objetivos (0).

- Caso faça uso de outra(s) ferramenta(s) nāo listada(s), utilize o campo "Outros".

\section{Q Fórum:}

ME:

0

Blog:

ME:

0

Biblioteca virtual:

ME

0

Votador de dúvida:

ME:

$0:$

Vídeo aulas:

ME:

o: 
ME:

0 :

$\square \quad$ Videoconferência:

ME:

0 :

$\square \quad$ Games:

ME:

0 :

$\square \quad$ Ferramentas de ediçẫo compartilhada de documentos on-line. Ex: coop̣o Doc:

ME:

0 :

$\square$ Podcasts:

ME:

0 :

$\square \quad$ Plataforma de compartilhamento de videos. Ex: Youtube:

ME:

o:

Apresentações Eletrônicas:

ME:

0 : 


\section{UNIVERSIDADE DE SÃO PAULO}

ESCOLA DE ENFERMAGEM

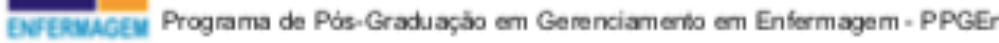

$\square$ Realidade Virtual:

ME:

0 :

Realidade Aume ntada:

ME:

0:

$\square \quad$ Ambiente Virtual de Aprendizagem:

ME

0

$\square$ Questionário:

ME

0 :

$\square$ Diário de bordo:

ME:

0:

$\square \quad$ Wiki:

ME:

0:

$\square$ Glossário:

ME:

0 :

$\square$ Tarefas: 

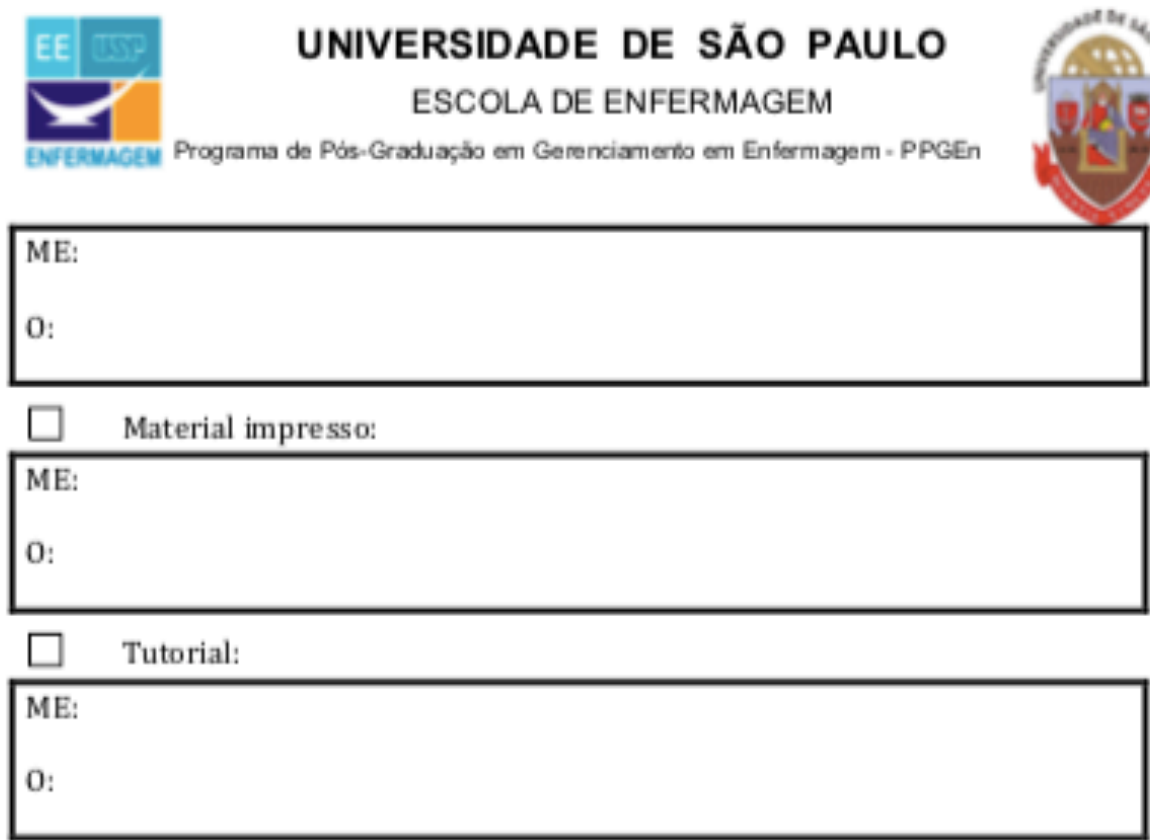

$\square$ Outros:

PARA USO DO PESQUISADOR:

INSTITUIÇÃo:

PARTICIPANTE: 


\section{Apêndice 3}

USP - ESCOLA DE
ENFERMAGEM DA
UNIVERSIDADE DE SÃO

\section{PARECER CONSUBSTANCIADO DO CEP}

\section{DADOS DO PROJETO DE PESQUISA}

Titulo da Pesquisa: METOdOLOG LAS DE ENS INO NA EDUCAÇÃo A DISTÁNCIA EM CIÊNCIA DA SAUUDE: FORMACÁA LATO SENSU.

Pesquisador: DANIELE SOARES CARLIN

Area Temática:

Versåo: 2

CAAE: 78051717.1 .0000 .5392

Instituiçâo Proponente: Escola de Enfermagem da Universidade de Sáo Paulo - EEUSP

Patrocinador Principal : Finandiamento Prćprio

\section{DADOS DO PARECER}

Número do Parecer: 2.384 .492

\section{Apresentaçáo do Projeto:}

A crescente evoluçấo tecnolbgica trouxe consigo novas formas de se relacionar e de aprender. Nesse contexio, temos a possbilidade de estudar btalmente à distância - e-leaming - e também parcialmente à distancia - blended-leaming. Para que essas novas formas de aprendizagem se estabeleçam com qualidade, novas metodologias de ensino predisam ser trabalhadas e implementadas para o alcance do uso de novas estratégias, a fim de adequar-se ao contexto dessa nova malidade, como base para o avanço do conhecimento, também nas ciènclas da saúde.

\section{Objetivo da Pesquisa:}

Analisar as melodologias de ensino na modalidade Educaçâo à Distância - EAD, em cursos lało sensu, nas áreas da Ciência da Saúde.

a. Conhecer melodologias de ensino em cursos lab sensu que ulilizam EAD;

b. Identificar as inovaçðes metodolbgicas presentes nesses cursos;

c. Destacar componentes das metodologias de ensino destes cursos;

d. Disinguir os componentes que se relacionam e inserem essas metodologias no ensino lab sensu dos cursos destacados

\section{Avaliaçâo dos Riscos e Beneficios:}

A pesquisa nâo apresenta beneficios diretos aos particpantes da investigaçâo.

O riscos existente refese-se ao desconfono ao responder ao questionário.

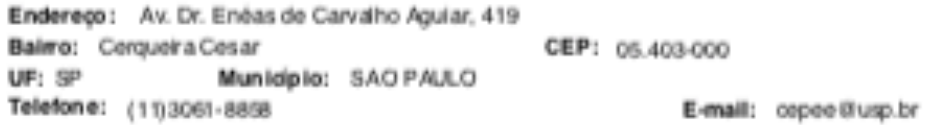




USP - ESCOLA DE
ENFERMAGEM DA
UNIVERSIDADE DE SÃO

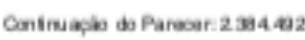

Comentários e Consideraçôes sobre a Pesquisa:

O pesquisador atendeu às pendências anteriores.

Consideraçóes sobre os Termos de apresentaçăo obrigatória:

Năo há considerą̧ðos.

Recomendaçóes:

Năo há recomendap̧oses.

Conclusóes ou Pendências e Lista de Inadequaçóes:

Năo há bbices éticos.

Consideraçóes Finais a critério do CEP:

- Este CEP informa a necessidade de registro dos resultados parciais e finais na Plataforma Brasil;

- Esta aprovaçâo nåo subsutui a autorizaçâo da instituiçâo copar tcipante, antes do inicio da coleta de dados.

Este parecer foi elabor ado baseado nos documentos abaixo relacionados:

\begin{tabular}{|c|c|c|c|c|}
\hline Tpo Documento & Arquivo & Postagem & Autor & Stuaçấo \\
\hline $\begin{array}{l}\text { Informap̧es Básicas } \\
\text { do Proiefo }\end{array}$ & $\begin{array}{l}\text { PB_INFORMACOES_BASICAS_DO_P } \\
\text { RO.JETO 1003934_pdt }\end{array}$ & $\begin{array}{l}31 / 10 / 2017 \\
1230.06\end{array}$ & & Aceilo \\
\hline $\begin{array}{l}\text { Projeto Detalhado / } \\
\text { Brochura } \\
\text { investigador }\end{array}$ & Projeto_cepv2.docx & $\begin{array}{c}31 / 10 / 2017 \\
12.29: 42\end{array}$ & $\begin{array}{l}\text { DANIELE SOARES } \\
\text { CARLN }\end{array}$ & Aceilo \\
\hline $\begin{array}{l}\text { TCLE / Termos de } \\
\text { Assentimento / } \\
\text { Justicativa de } \\
\text { Ausência }\end{array}$ & $\begin{array}{l}\text { TERMO_DE_CONSENTIMENTO_LIVR } \\
\text { E_E_ESCLARECIDO_docx }\end{array}$ & $\begin{array}{l}02 / 10 / 2017 \\
14.06: 52\end{array}$ & $\begin{array}{l}\text { DANIELE SOARES } \\
\text { CARUN }\end{array}$ & Aceito \\
\hline Cronograma & cronograma_cep.doc & $\begin{array}{c}02 / 10 / 2017 \\
14.02228\end{array}$ & $\begin{array}{l}\text { DANIELE SOARES } \\
\text { CARUN }\end{array}$ & Aceib \\
\hline Follha de Rosio & pditAss_Diretora.pdf & $\begin{array}{c}29,09 / 2017 \\
16: 13.38\end{array}$ & $\begin{array}{l}\text { DANIELE SOARES } \\
\text { CARUIN }\end{array}$ & Acelio \\
\hline
\end{tabular}

Situaçăo do Parecer:

Aprovado

Necessita Apreciaçăo da CONEP:

Naso

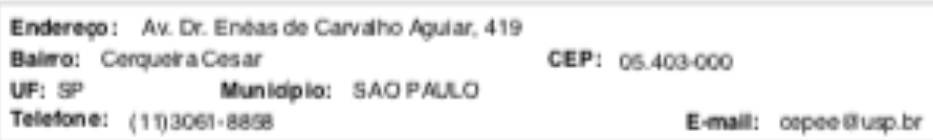

